\title{
ONTOGENETIC NICHE SHIFT IN THE BRACHIOPOD TEREBRATALIA TRANSVERSA: RELATIONSHIP BETWEEN THE LOSS OF ROTATION ABILITY AND ALLOMETRIC GROWTH
}

\author{
by ADAM TOMAŠOVÝCH*†, SANDRA J. CARLSON† and \\ MICHAEL LABARBERA $\$$ \\ ${ }^{\star}$ Department of Geophysical Sciences, University of Chicago, 5734 S. Ellis Ave., Chicago, Illinois 60637, USA \\ †Geological Institute, Slovak Academy of Sciences, Dúbravská cesta 9, 84005 Bratislava, Slovakia, E-mail: tomasovych@uchicago.edu \\ †Department of Geology, University of California, Davis, California 95616, USA, E-mail: carlson@geology.ucdavis.edu \\ §University of Chicago, Department of Organismal Biology and Anatomy, 1027 East 57th Street, Chicago, Illinois 60637, USA, mlabarbe@uchicago.edu \\ Typescript received 5 April 2008; accepted in revised form 20 August 2008
}

\begin{abstract}
Many articulated brachiopods experience marked life habit variations during ontogeny because they experience their fluid environment at successively higher Reynolds numbers, and they can change the configuration of their inhalant and exhalant flows as body size increases. We show that the extant brachiopod Terebratalia transversa undergoes a substantial ontogenetic change in reorientation governed by rotation around the pedicle. T. transversa's reorientation angle (maximum ability to rotate on the pedicle) decreases during ontogeny, from 180 degrees in juveniles to 10-20 degrees in individuals exceeding $5 \mathrm{~mm}$, to complete cessation of rotation in individuals larger than $10 \mathrm{~mm}$. Rotation ability is substantially reduced after $T$. transversa achieves the adult lophophore configuration and preferred orientation with respect to ambient water currents at a length of $2.5-5 \mathrm{~mm}$. We hypothesize that the rotation angle of $T$. transversa is determined mainly by the position of ventral and dorsal points of attachment of dorsal pedicle muscles relative to the pedicle. T. transversa shows a close correlation between the ontogenetic change in reorientation angle and ontogeny of morphological traits that are related to points of attachment of dorsal pedicle muscles, although other morphological features can also limit rotation in the adult stage. The major morphological change in cardinalia shape and the observed
\end{abstract}

reduction of rotation affect individuals $2.5-10 \mathrm{~mm}$ in length. The position of ventral insertions of dorsal pedicle muscles remains constant, but contraction of dorsal pedicle muscles is functionally handicapped because dorsal insertions shift away from the valve midline, rise above the dorsal valve floor, and become limited by a wide cardinal process early in ontogeny $(<5 \mathrm{~mm})$. The rate of increase of cardinal process width and of distance between dorsal pedicle muscle scars substantially decreases in the subadult stage $(5-10 \mathrm{~mm})$, and most of the cardinalia shell traits grow nearly isometrically in the adult stage $(>10 \mathrm{~mm})$. T. transversa attains smaller shell length in crevices than on exposed substrates. The proportion of small-sized individuals and population density is lower on exposed substrates than in crevices, indicating higher juvenile mortality on substrates prone to grazing and physical disturbance. The loss of reorientation ability can be a consequence of morphological changes that strengthen substrate attachment and maximize protection against biotic or physical disturbance (1) by minimizing torques around the pedicle axis and/or (2) by shifting energy investments into attachment strength at the expense of the cost involved in reorientation.

Key words: Brachiopoda, ecomorphology, palaeoecology, functional morphology, ontogeny, allometry, pedicle.
ARTICULATED brachiopods are epifaunal suspensionfeeders that dominated benthic communities in the Palaeozoic and early Mesozoic (Rudwick 1970; Williams and Hurst 1977; Sepkoski and Miller 1985; Aberhan 1994), but have relatively restricted geographic ranges and low abundances in modern seas (Richardson 1997; Zezina 2001; Logan 2007). Variation in ecological traits among brachiopod species (Rudwick 1970; Richardson 1981a; Valentine and Jablonski 1983; Logan et al. 2004, Álvarez et al. 2005) and in genetics of extant brachiopod populations (Ayala et al. 1975; Cohen et al. 1991, 1993; Ostrow et al. 2001; Lüter and Cohen 2002) is relatively low in comparison to other benthic suspension-feeders such as bivalves (Stanley 1970; Bush et al. 2007; Novack-Gottshall 2007). The difference in ecological performance between articulated brachiopods and other successful suspension-feeders 
is generally attributed to morphological and physiological traits associated with their low metabolic rates (Bambach 1993; Rhodes and Thompson 1993; Peck 1996), lack of mobility (e.g. inability to actively escape from predation, inability to re-attach after dislodgment, or reduced ability to change orientation with respect to water currents) and lack of infaunality (Vermeij 1977; LaBarbera 1981; Thayer 1983, 1985; Lescinsky 1995; Leighton 2000; Kowalewski et al. 2005; Aberhan et al. 2006; Madin et al. 2006), although other factors such as differences in dispersal may also govern their differential ecological and evolutionary success (Valentine and Jablonski 1983). The secular decline in the diversity and abundance of brachiopods has been hypothesized to be driven by increased consumer (including predation and grazing) and competition pressure initiated in the late Mesozoic (Vermeij 1977). Articulated brachiopods typically fix themselves to hard substrata by means of a pedicle after larval settlement. Most of the extant brachiopods remain fixed with the pedicle throughout life and use it as an anchor and/or as an adjusting appendage (Surlyk 1972; Bromley and Surlyk 1973; LaBarbera 1977; Richardson 1981b; Curry 1981; Bassett 1984; Emig 1989). Several species such as Magadina cumingi and Neothyris lenticularis change from a pedunculate to a free-lying life mode during ontogeny because they develop morphological traits (e.g. differential thickening in posterior shell parts) that enable a more stable position and restricted mobility on soft sediment (e.g. Manceñido and Walley 1979; Richardson 1981a, 1987, 1997; Richardson and Watson 1975; Curry 1983; Alvarez 1990; Brunton 1996; Dattilo 2004; Simões et al. 2007). On hard substrates, types of pedicle attachment and development of pedicle muscles affect reorientation ability with respect to water currents (LaBarbera 1977; Richardson 1981a), resistance to dislodgement (Thayer 1975), and avoidance of overgrowth by other sessile benthos (LaBarbera 1985).

In this study, we evaluate an ontogenetic shift in reorientation ability and a corresponding change in morphology of cardinalia and pedicle muscle scars of a hard-substrate-dwelling brachiopod. First, we address theoretical predictions for the rotation ability of brachiopods that follow from the biomechanics of their pedicle and pedicle muscles. Second, we document an ontogenetic shift in rotation ability in a brachiopod, Terebratalia transversa that inhabits hard-bottom habitats of the Northeastern Pacific (Atkins 1959; Thayer 1975, 1977; Buening and Carlson 1992; Krause 2004; Logan 2007). Although Terebratalia does not rotate in the adult stage (LaBarbera 1977, 1978), the rate and timing of its rotation loss remain unexplored. Third, to evaluate the hypothesis that the change in rotation ability is determined by ontogenetic changes in the dorsal pedicle muscles, we quantify ontogenetic variation in size and shape of dorsal pedicle muscle scars in Terebratalia transversa with traditional and landmark-based morphometric analyses. Fourth, we infer functional and ecological consequences of allometric growth of dorsal pedicle muscle attachment sites (e.g. Ricklefs and Miles 1994; Wainwright 1994; Koehl 1996). We focus on dorsal pedicle muscles because they were hypothesized to substantially affect the rotation of the shell (LaBarbera 1978) and they form clearly visible scars on internal shell structures in the posterior parts of the dorsal valve (i.e. cardinalia).

The functional analysis of reorientation ability is based on a simple geometric relationship that determines the rotation angle of the brachiopod shell around the pedicle (LaBarbera 1978). It can be used in autecological analyses of fossil brachiopods because such biomechanical principles are distinct from comparative approaches based on phylogenetic relationships and engineering approaches that hypothesize an optimal structure (Plotnick and Baumiller 2000). Comparative approaches may often assume that structures of fossil organisms function similarly to homologous structures in living relatives. However, this approach becomes less reliable with increasing phylogenetic distance (Plotnick 1985). Functional analyses that use engineering approaches in testing the function of biological structures often assume that such structures were optimized by natural selection (Gould and Lewontin 1979; Seger and Stubblefield 1996).

Although the role of pedicle muscles in determining reorientation behaviour was evaluated in several extant brachiopods in their adult stage (LaBarbera 1978; Richardson 1975, 1981a, 1981b, 1994, 1997; Richardson and Mineur 1981), ontogenetic changes in pedicle and pedicle muscles are poorly known. In addition, although variations in hinge-system geometry and in mantle cavity volume and lophophore complexity were explored in several studies (e.g. Fürsich and Hurst 1974; McGhee 1980; Carlson 1989, 1992; Aldridge 1998, 1999), temporal and spatial changes in rotation ability also remain unexplored.

\section{PEDICLE AND PEDICLE MUSCLES}

Dorsal pedicle muscles govern a brachiopod's ability to rotate its shell around the pedicle because they are situated approximately perpendicular to the longitudinal axis of the pedicle - they thus produce torques around the pedicle axis (LaBarbera 1978). Ventral pedicle muscles govern the ability to tilt and depress the shell with respect to the substrate and also affect its attachment strength. Ventral pedicle muscles mostly lie subparallel to the pedicle axis and thus do not affect shell rotation around the pedicle (LaBarbera 1978). The rotation of a brachiopod shell around the pedicle depends on three parameters (Text-fig. 1), including (1) the angle $(\alpha)$ determined by the position of attachment sites of dorsal pedicle muscles 


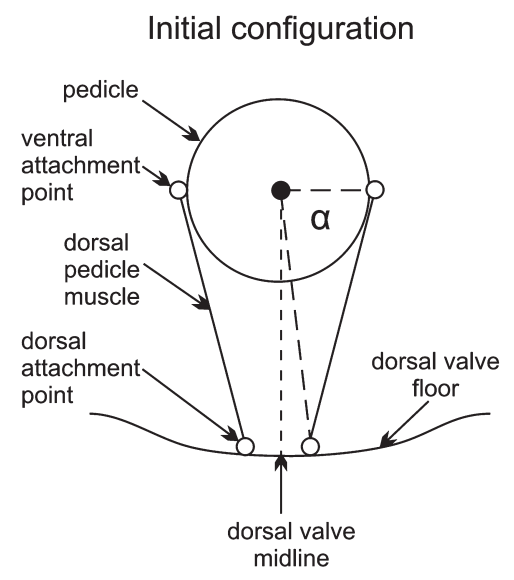

Initial configuration

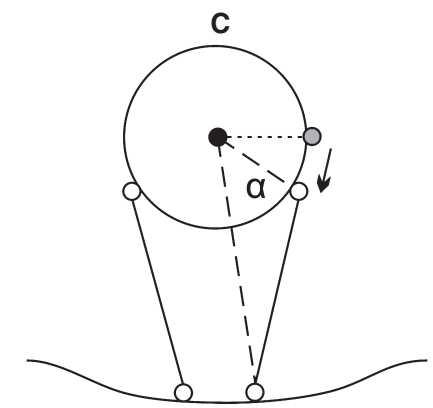

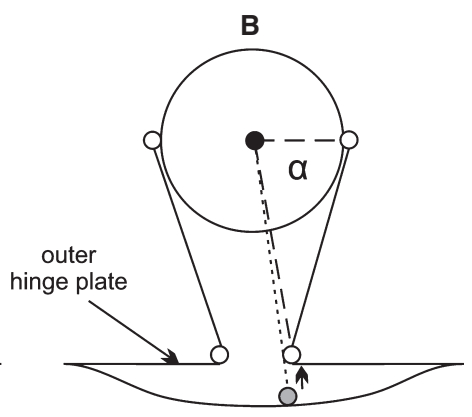

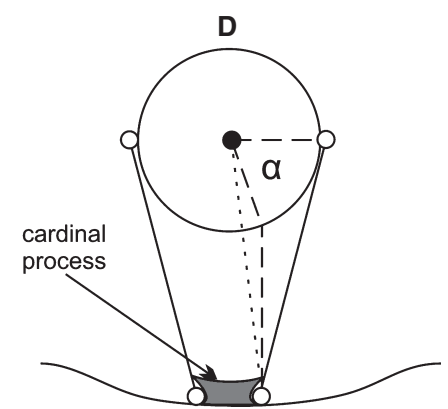

TEXT-FIG. 1. Predicted changes in the angle $\alpha$ that determines rotation around the pedicle, based on the geometric relationship between the pedicle (large circle) and ventral and dorsal attachment points of the dorsal pedicle muscles. Four possible changes can reduce rotation angle during ontogeny: A, Dorsal attachment points shift in a horizontal direction. B, Dorsal attachment points shift in a vertical direction. C, Ventral attachment points shift in a vertical and horizontal direction. D, Rotation angle is constrained by wide cardinal process and diductor muscle.

on the pedicle and on the dorsal valve (LaBarbera 1978), (2) the shape of the pedicle bulb at the insertions of the dorsal pedicle muscles, and (3) the cross-sectional area of the dorsal pedicle muscles (LaBarbera 1978). We note that although changes in these parameters might result directly from acclimatization or from selection pressure on reorientation ability, changes (or lack of changes) in morphology that constrain rotation can also be a secondary consequence of development of other traits that also affect these parameters, such as shell convexity or hinge geometry. The three parameters are described in detail below.

(1) In an anterior view, parallel with the pedicle stalk and approximately perpendicular to the dorsal pedicle muscles (Text-fig. 1), the rotation of the shell around the pedicle produced by contraction of the dorsal pedicle muscles can be quantified by the angle $\alpha$ (Text-fig. 1) (LaBarbera 1978). The expected net rotation of the shell around the pedicle is $2 \alpha$. The ventral side of angle $\alpha$ is determined by the position of ventral attachment sites of dorsal pedicle muscles to the pedicle. The dorsal side of angle $\alpha$ is determined by the position of dorsal attachment points of dorsal pedicle muscles relative to the pedicle. This position depends on the vertical distance between the pedicle and dorsal attachment sites of dorsal pedicle muscles, and on the horizontal distance between dorsal attachment sites of dorsal pedicle muscles and dorsal valve midline (Text-fig. 1). Dorsal attachment sites of dorsal pedicle muscles are usually preserved as wellmarked depressions on the dorsal valve owing to shell resorption (MacKinnon 1977; Williams and Hewitt 1977). Although ventral attachment sites of pedicle muscles to the pedicle are not preserved on brachiopod shells, evaluating ontogenetic relationships among pedicle opening diameter, distance between scars of dorsal pedicle muscles, scar elevation, and shell length can indicate whether and to what degree the rotation angle changes during ontogeny in Terebratalia transversa.

If the geometry of the pedicle and attachment sites of pedicle muscles change isometrically with an increase in shell length, the angle $\alpha$ is expected to remain constant (Text-fig. 1). In this case, ventral attachment sites of dorsal pedicle muscles have to grow in a ventral direction at the same rate as the pedicle diameter grows. Although between-scar distance is expected to increase under isometric growth (i.e. dorsal attachment points shift laterally from midline, thus decreasing the angle $\alpha$ ), the depth of dorsal attachment point is simultaneously increasing under isometric growth, thus keeping the angle $\alpha$ constant. However, dorsal attachment points of dorsal pedicle muscles may change their position because cardinalia are generally elevated above the dorsal valve floor in the adult 
stage (Lee et al. 2006). In this case, dorsal attachment points of dorsal pedicle muscles shift in a vertical direction, and the angle $\alpha$ can decrease. Several predictions arise from the ontogenetic change of the attachment sites of the dorsal pedicle muscles (Text-fig. 1). First, an allometric shift of dorsal attachment points away from the dorsal valve midline will decrease the angle $\alpha$ (Textfig. 1A). Second, any vertical shift of attachment points above the dorsal valve floor during ontogeny will decrease the angle $\alpha$ (Text-fig. 1B). Third, a shift of ventral attachment points in the dorsal direction will decrease the angle $\alpha$ (Text-fig. 1C). Fourth, an allometric growth of pedicle diameter may lead to a shift of ventral muscle insertions. The junction between pedicle epithelium and outer mantle epithelium forms a ring that is attached to the posteromedian part of the brachiopod shell (Williams and Hewitt 1977; Mackay and Hewitt 1978). During ontogeny, the junction associated with the pedicle and pedicle capsule is enlarged and migrates in an anterior direction, and proliferation of cells takes place within generative zones of the pedicle epithelium. However, it is difficult to predict whether a change in pedicle diameter will affect insertion of the dorsal pedicle muscles on the pedicle because it remains unknown whether enlargement of the pedicle follows from localized or more general cell generation.

In addition to dorsal attachment points of dorsal pedicle muscles, the dorsal side of the angle $\alpha$ is likely to be constrained by the diductor muscle and its dorsal attachment point, the cardinal process (Text-fig. 1D). Although the cardinal process lies posterior to the dorsal attachment points of the dorsal pedicle muscles (Brunton et al. 1996), the diductor muscles that attach to the cardinal process run anteroventrally toward the ventral valve. Therefore, a wide tendon of the diductor muscle can constrain contraction of dorsal pedicle muscles and restrict pedicle rotation because the ventral insertion of the dorsal adjustor on the pedicle cannot be rotated into line with a line connecting the pedicle axis with the dorsal attachment point of the dorsal adjustor muscle (Text-fig. 1D).

(2) The outline of the pedicle bulb (i.e. proximal, slightly expanded part of the pedicle) in anterior, crosssectional view can partly determine the angle $\alpha$ and rotation ability (LaBarbera 1978). Everything else being equal and keeping the diameter of the pedicle bulb constant, individuals with a circular outline of the pedicle bulb can have a better ability to rotate than individuals with pedicle bulbs elongated along the right-left axis.

(3) A change in size of the dorsal attachment area of dorsal pedicle muscles, measured by a change in adjustor scar size, can cause a change in rotation ability (e.g. Chapman and Richardson 1981). This prediction follows from the approximation that the cross-sectional area of a muscle at resting length is proportional to the force that the muscle is capable of generating.

\section{METHODS}

\section{Reorientation ability}

To evaluate the rate and timing of reorientation loss during ontogeny of the juvenile and subadult Terebratalia, estimates by Carlson (1983, 1986, 1987a, 1987b) and new estimates based on observations of nine juvenile and subadult individuals of Terebratalia transversa (this study) are considered. Carlson (1983, 1986, 1987a, 1987b) placed brachiopods attached either to a scallop or other brachiopods in a Plexiglas flow chamber under current velocities of $1-2 \mathrm{~cm} / \mathrm{s}$. Reorientation of Terebratalia transversa was directly observed under a binocular microscope placed above the flow chamber. In this study, brachiopods attached to live individuals of the mussel Modiolus modiolus cleaned of benthic settlers were placed in a Plexiglas flow chamber and observed under current velocities of $10 \mathrm{~cm} / \mathrm{s}$. In both studies, the change in orientation of brachiopods was measured after 24 hours. Live individuals of Modiolus modiolus were oriented so that the anterior margin of brachiopods faced the water current either upstream or downstream. The initial orientation of brachiopods was marked by a thin groove on the mussel valve that was parallel to the anterior-posterior axis of the brachiopod shell in the initial position because Modiolus individuals commonly reoriented themselves during the observed time period. After 24 hours of exposure to the current, a new groove parallel to the anterior-posterior axis of a brachiopod shell was marked on the mussel valve and the resulting pattern was photographed under a microscope (Text-fig. 2). Individuals were not filmed during the whole time period and the observed angles thus represent minimum estimates of reorientation ability.

\section{Pedicle muscles}

Six freshly dead individuals were dehydrated for several days in alcohol and then dried. Their valves were opened sufficiently to see the attachment of the dorsal pedicle muscles to the dorsal valve and the pedicle in anterior view. Three individuals with 2.2, 3.2, and $5.5 \mathrm{~mm}$ long dorsal valves were photographed using a scanning electron microscope (SEM, Text-fig. 3A-C). Three adult individuals reaching $20-21 \mathrm{~mm}$ in length were photographed under a light microscope (Textfig. 3D-F). The angle $\alpha$ was directly measured on shells with preserved muscles. 

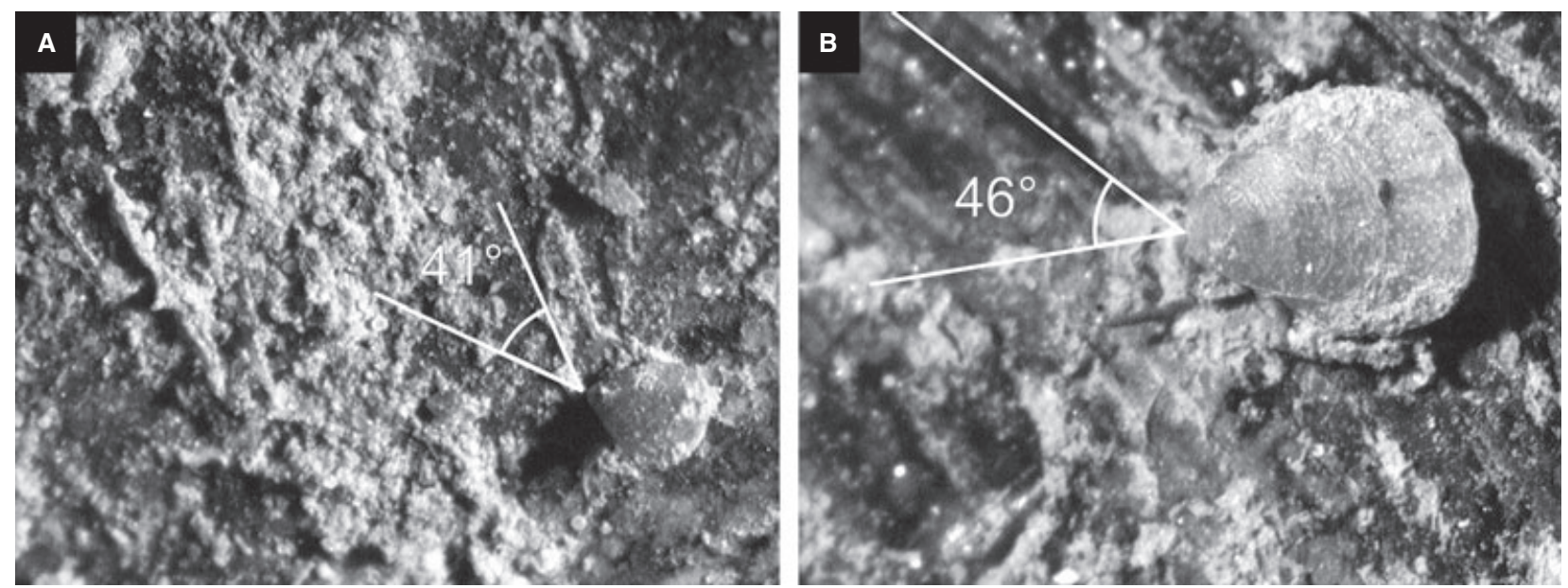

TEXT-FIG. 2. Examples of the rotation angle exhibited by Terebratalia transversa juveniles after 24 hours when attached to the mussel Modiolus modiolus. In initial position, juveniles were oriented with their anterior margin upstream.

\section{Traditional morphometrics}

We analyse size and shape changes of cardinalia with traditional and landmark-based morphometrics. On the one hand, the hypotheses predicting rotation ability are explicitly phrased in terms of the between-scar distance, the size of attachment scars, and the size of the pedicle bulb, and traditional morphometrics is thus suitable for their testing. On the other hand, landmark-based morphometrics allows rigorous comparison of complex shapes by simultaneously detecting shape variation of other characters of the cardinalia beside the adjustor scars, including the diductor scars (cardinal process), the socket ridges, and the crural bases.

All shells analysed were sampled by a dredge near the western side of the San Juan Channel in rocky subtidal habitats at depth of $60-80 \mathrm{~km}$ (Rock Point, Lopez Island, Washington State). Digitized cardinalia of 189 dorsal valves were based on camera lucida drawings because light-microscope photographs of individuals over $3 \mathrm{~cm}$ in length did not have sufficient contrast for detection of morphological boundaries. 13 morphological traits were measured on dorsal valves of 189 individuals (Textfig. 4A; Table 1). Dorsal valves range from 1 to $25 \mathrm{~mm}$ in length and thus cover the ontogenetic size range of Terebratalia transversa. Pedicle opening diameter was measured on the ventral valves of 165 individuals and shell thickness on shells of 155 individuals. All individuals are deposited in the Slovak National Museum (Bratislava).

The ontogenetic series was subdivided into five size segments. Juvenile stages less than $2.5 \mathrm{~mm}$-long are characterized by trocholophe and schizolophe lophophores, juvenile stages $2.5-5 \mathrm{~mm}$-long are characterized by zygolophe lophophores (Text-figs 5-6), and subadult stages 5$10 \mathrm{~mm}$-long are characterized by plectolophe lophophore
(Atkins 1959). Individuals smaller than $10 \mathrm{~mm}$ are generally less than two years old (Thayer 1977). Because Terebratalia transversa can live for at least seven years (Paine 1969; Buening and Carlson 1992; Auclair et al. 2003), the adult stage (10-25 mm in length) was subdivided into two classes for descriptive purposes, with the arbitrary breakpoint at $17.5 \mathrm{~mm}$.

The relationship among size classes and shell traits was explored using principal component analysis (PCA) of the 15 log-transformed shell traits, based on the variancecovariance matrix. Bivariate and multivariate allometric coefficients evaluate relationships among log-transformed shell traits related to dorsal pedicle muscle attachment (i.e. distance between adjustor scars, scar size, cardinal process size, and pedicle opening diameter) and ontogenetic size measures. Size is represented by centroid size (independent variable in least-square regressions [LSR]) computed from nine landmarks defined on cardinalia (see below), and dorsal valve length (dependent variable in reduced major axis regressions [RMA]). The centroid size is defined as the square root of the sum of squared distances between each landmark and the centroid of the configuration, based on landmark configuration in Text-fig. 4B (Bookstein 1991). The multivariate allometric coefficient for a given shell trait is estimated by dividing the PC1 loading for that variable by the mean PC1 loading over all variables (Jolicoeur 1963; Kowalewski et al. 1997). Regressed slopes of log-transformed traditional measurements on log-transformed dorsal valve length, log-transformed centroid size, and PC 1 are expected to be significantly different from a value of one under allometry.

Three methods explore non-linearity of ontogenetic shape change, test whether complex allometry (i.e. allometric trajectory is nonlinear and the allometric coefficient is not constant during the ontogeny, e.g. 

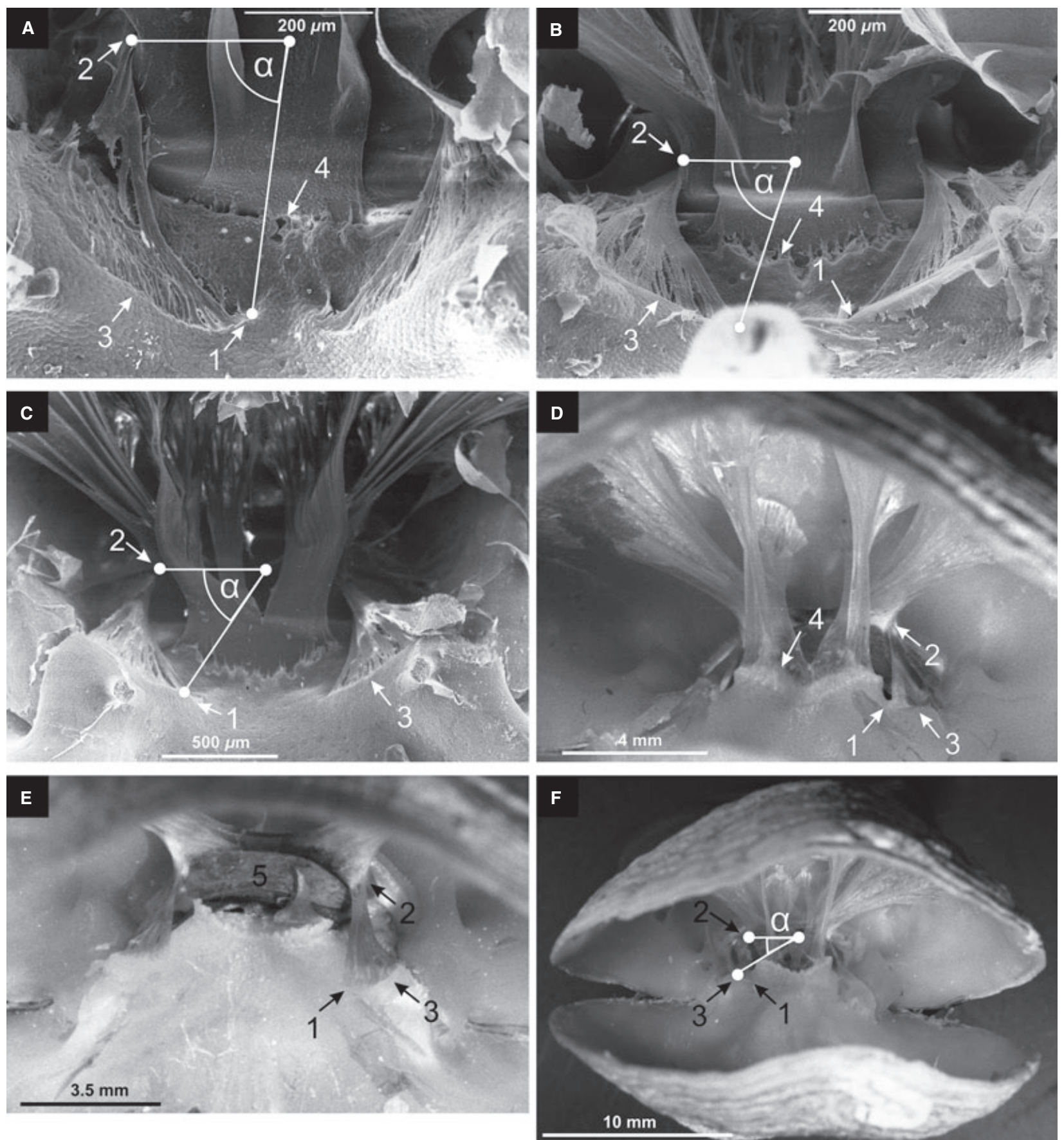

TEXT-FIG. 3. Ontogenetic change in position of dorsal (1) and ventral attachment points (2) of the dorsal pedicle muscles relative to the pedicle, in elevation of outer hinge plates above the dorsal valve floor (3), in width of the cardinal process (4), and in shape of the pedicle bulb (5) in Terebratalia transversa (anterior views). Outer hinge plates (3) are only slightly elevated above the dorsal valve floor in the juvenile stage (A-B), and they are strongly elevated above the valve floor in the adult stage (D-F). The distance between median attachment points of dorsal pedicle muscles increases from the juvenile to the adult stage. A, Ventral valve length is 2.9 mm. $\mathrm{B}$, Ventral valve length is $4 \mathrm{~mm}$. C, Ventral valve length is $7.1 \mathrm{~mm}$. D, Ventral valve length is $24.9 \mathrm{~mm}$. E, Ventral valve length is $22.9 \mathrm{~mm}$. F, Ventral valve length is $25.9 \mathrm{~mm}$. Figures A-C were obtained using a scanning electron microscope and figures D-F were photographed under a light microscope.

Bookstein 1991; Zelditch et al. 1993) can better explain ontogenetic trajectories than simple allometry, and evaluate whether rates of shape change of juveniles differ from those of adults. First, we evaluate residuals of shell traits regressed on the centroid size and dorsal valve length. Second, we compare differences in regression slopes 
TEXT-FIG . 4. Summary of morphological dimensions (A) and landmarks (B) used in morphometric analyses of cardinalia size and shape in Terebratalia transversa. The landmarks are defined as follows: (1) the posterior tip of the cardinal process, (2) intersection of the lateral point of the cardinal process with the posterior point of the inner socket ridge, (3)

intersection of the anterolateral tip of the inner socket ridge with the dental socket/outer hinge plate, (4) intersection of the posterolateral point of the crural base with the inner socket ridges, (5) intersection of the posteromedian point of the crural base with the outer hinge plate, (6) intersection of the posteromedian point of the outer hinge plate with the valve floor/cardinal process, (7) the anterior tip of the cardinal process, (8) the posteromedian point of the adjustor scar, in the most proximate position with respect to the median line, and (9) the anterolateral point of the adjustor scars, in the most distal position with respect to posterior hinge axis.
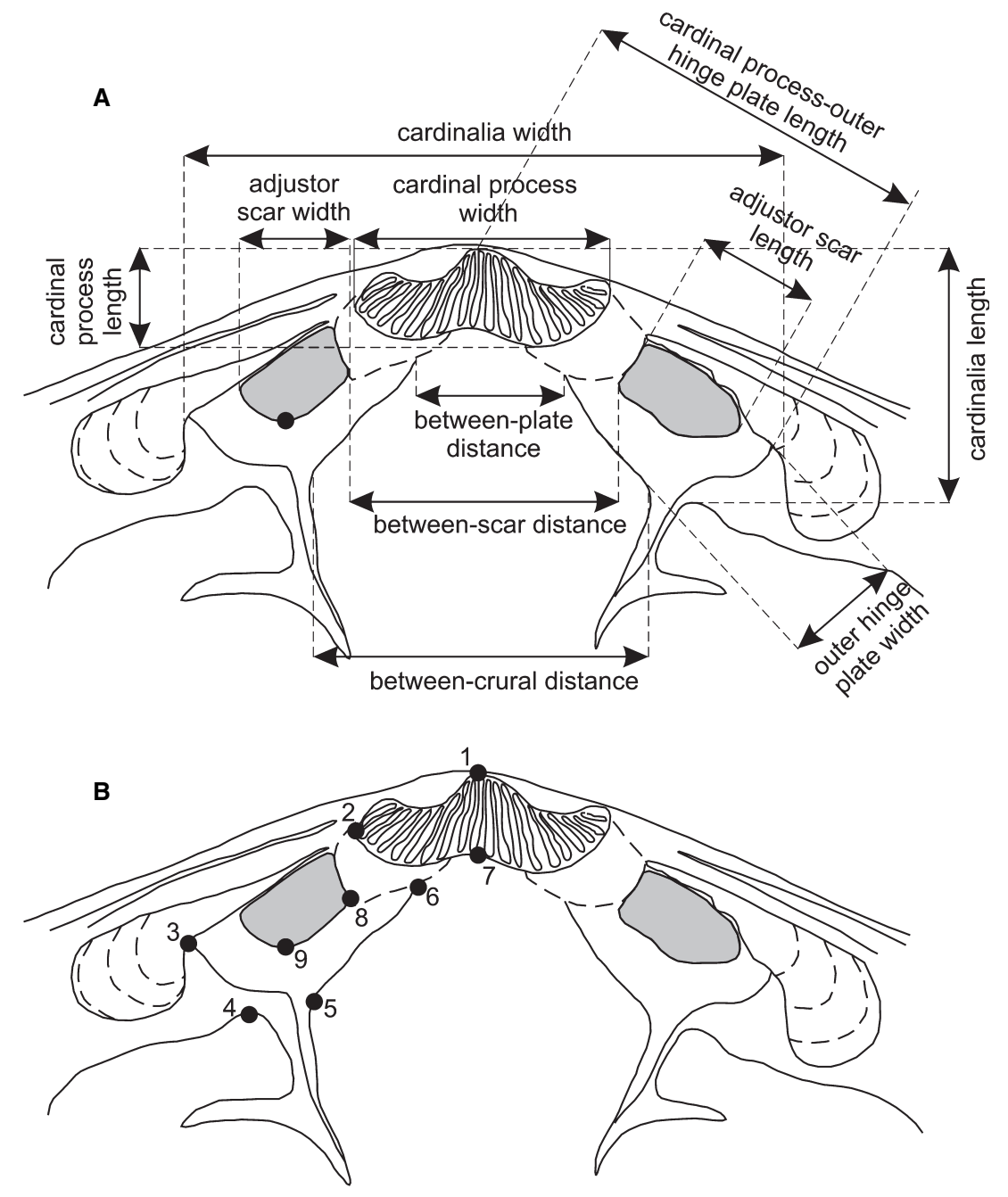

between juveniles and adults. Third, an F-test evaluates curvilinearity by testing the significance of reduction in the sum of squares of residuals between linear and second-order polynomial regression. This test is based on a ratio of the difference in sum of squares of residuals between the quadratic and linear model to the quadratic residual mean square (McKinney 1984). Differentiating the second order polynomial relationship (log trait size $=\mathrm{a}(\log \text { centroid size })^{2}+\mathrm{b}(\log$ centroid size $\left.)+c\right)$, one can derive an equation that approximates the slope (k) at any given size:

$$
\begin{aligned}
\mathrm{k} & =d \log \text { trait size } / d \log \text { centroid size } \\
& =2 \mathrm{a}(\log \text { centroid size })+\mathrm{b}
\end{aligned}
$$

The first derivative of the second order polynomial fit of the growth trajectory thus estimates the scaling exponent, corresponding to the growth ratio at a given centroid size (McKinney 1984; Allmon 1994). The change in $k$ along the ontogenetic trajectory thus represents the magnitude of the changes in growth ratio. Fourth, we use locally- weighted polynomial regression (the lowess function, $\mathrm{R}$ Development Core Team 2007) to estimate the centroid size that corresponds to the breakpoint of the fitted line curvature.

\section{Landmark-based morphometrics}

Nine discrete points (landmarks) that capture morphology of traits in the posterior parts of the dorsal valves were selected on 189 individuals (Text-fig. 4B). Landmarks were digitized with the TPS series of J. Rohlf (available at http://life.bio.sunysb.edu/morph), and analyses were performed with the Integrated morphometric package of D. Sheets (available at http://www.canisius. edu/ sheets/morphsoft.html). To evaluate the amount of error associated with landmark digitizing, two individuals randomly chosen from the smallest and the largest size classes were repeatedly digitized during ten consecutive days. The ten replicates for each individual were pooled 
TABLE 1. 15 morphological dimensions measured on Terebratalia transversa.

\begin{tabular}{ll}
\hline Dimension & Description \\
\hline $\begin{array}{l}\text { dorsal valve length } \\
\text { dorsal valve width }\end{array}$ & Distance between the posterior and the anterior valve margin \\
shell thickness & Distance between the lateral valve margins \\
pedicle opening diameter & Distance between the dorsal and ventral shell margins \\
cardinalia width & Distance between lateral margins of the pedicle opening \\
cardinalia length & Distance between the lateral tips of the cardinal process \\
& Distance between the posterior tip of the cardinal process and \\
outer hinge plate length & the anteromedian tip of the inner socket ridge \\
& Distance between the posterior tip of the cardinal process and \\
outer hinge plate width & the anterolateral point of the inner socket ridge \\
& Distance between the anteromedian tip of the outer hinge plate \\
between-crural distance & and posterolateral edge of the inner socket ridge \\
between-plate distance & Distance between crural bases \\
adjustor scar length & Distance between outer hinge plates \\
cardinal process width & Distance between the most anterior and the most posterior point of adjustor scar \\
cardinal process length & Distance between the lateral points of the cardinal process \\
between-scar distance & Distance between the anterior and posterior tip of the cardinal process \\
adjustor scar width & Distance between the posteromedian margins of adjustor scars \\
& Transversal distance between the anterolateral and the \\
& posteromedian point of adjustor scar
\end{tabular}

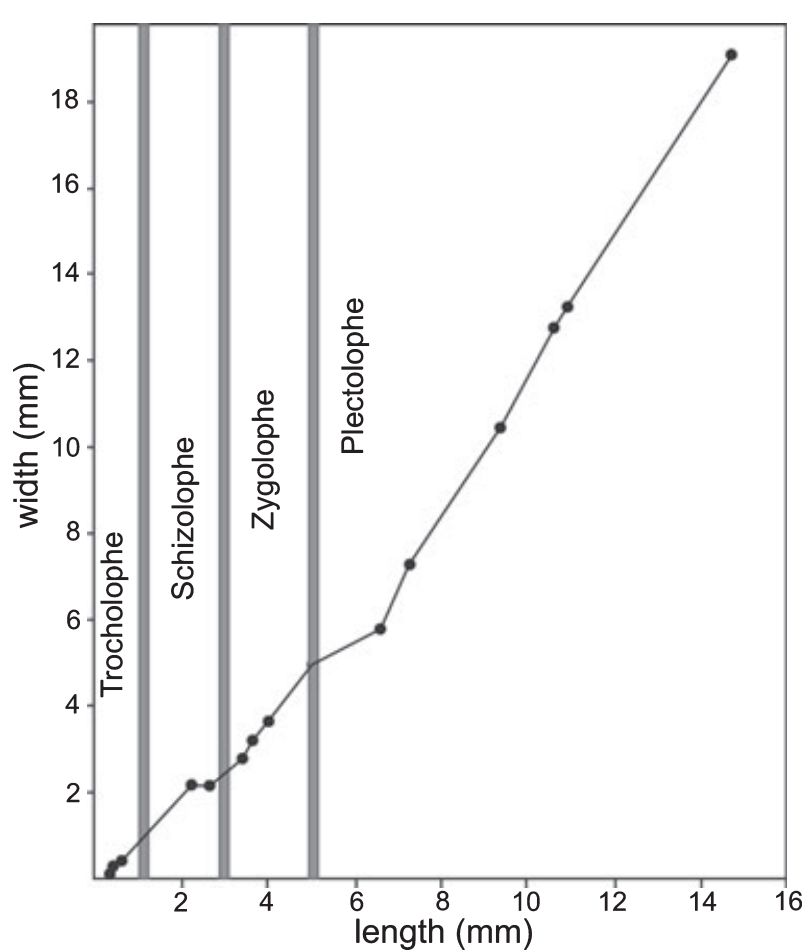

TEXT-FIG. 5. Graph showing ontogenetic changes in the configuration of lophophore of Terebratalia transversa with respect to its shell size (according to Carlson 1986).

with the full dataset and landmark configurations were superimposed by the Procrustes method. Shape variation among 10 similar-sized individuals, expressed by the average squared partial Procrustes distance between the speci-

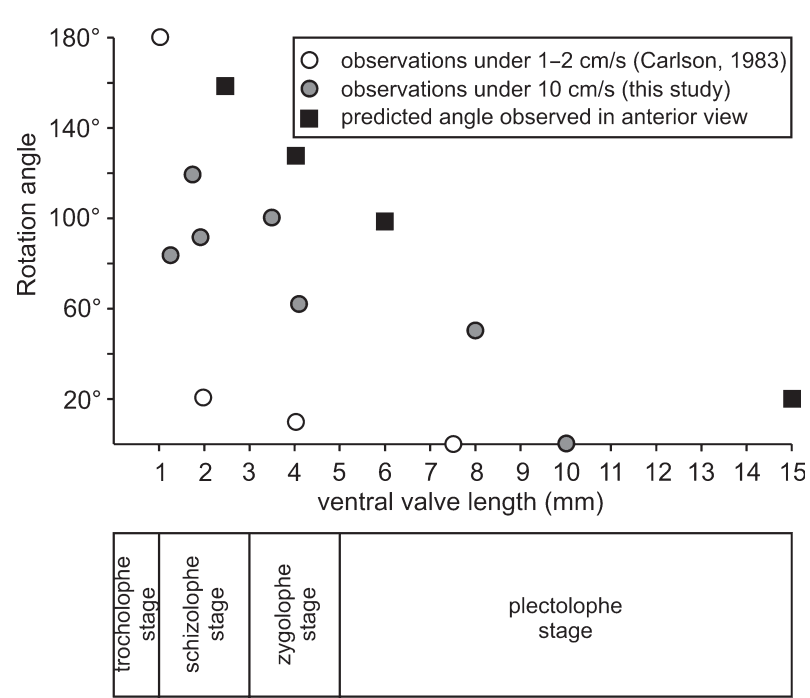

TEXT-FIG. 6. The predicted rotation angles $(2 \alpha)$ and the observed rotation angles of Terebratalia transversa under current speeds of $1-2$ and $10 \mathrm{~cm} / \mathrm{s}$ show a close correspondence for juveniles and subadults but also some offset because adult individuals larger than $10 \mathrm{~mm}$ should still be able to show net rotation of approximately 20-25 degrees.

mens and the group centroid (e.g. Foote 1993), is one order of magnitude larger than shape variation among 10 replicates of one individual $(D[10$ juveniles $]=0.012$, $D \quad[10$ replicates of one juvenile $]=0.0011, D[10$ adults $]=0.016, D$ [10 replicates of one adult $]=0.0014)$. Measurement error is thus relatively small: repeated digitizing of specimens indicates that within-specimen 
measurement error is smaller than variation within and among size classes (Text-fig. 7).

To quantify shape differences of the muscle scars in the context of the whole cardinalia among five size classes, we perform principal component analysis (PCA) and canonical variate analysis (CVA). These ordinations are based on partial warp coordinate scores and a uniform component (zeroth partial warp score) that are derived from the generalized least-squares (GLS) Procrustes superposition of all landmark configurations (Bookstein 1991), with a mean reference specimen based on all individuals. Partial warp scores are coordinates of the space that forms a tangent plane to shape space with the reference specimen shape derived from the Procrustes superposition lying at the pole. The shape difference between the configurations of two individuals is represented by a partial Procrustes distance (i.e. the square root of the summed squared distances between landmarks on the two configurations following Procrustes superposition).

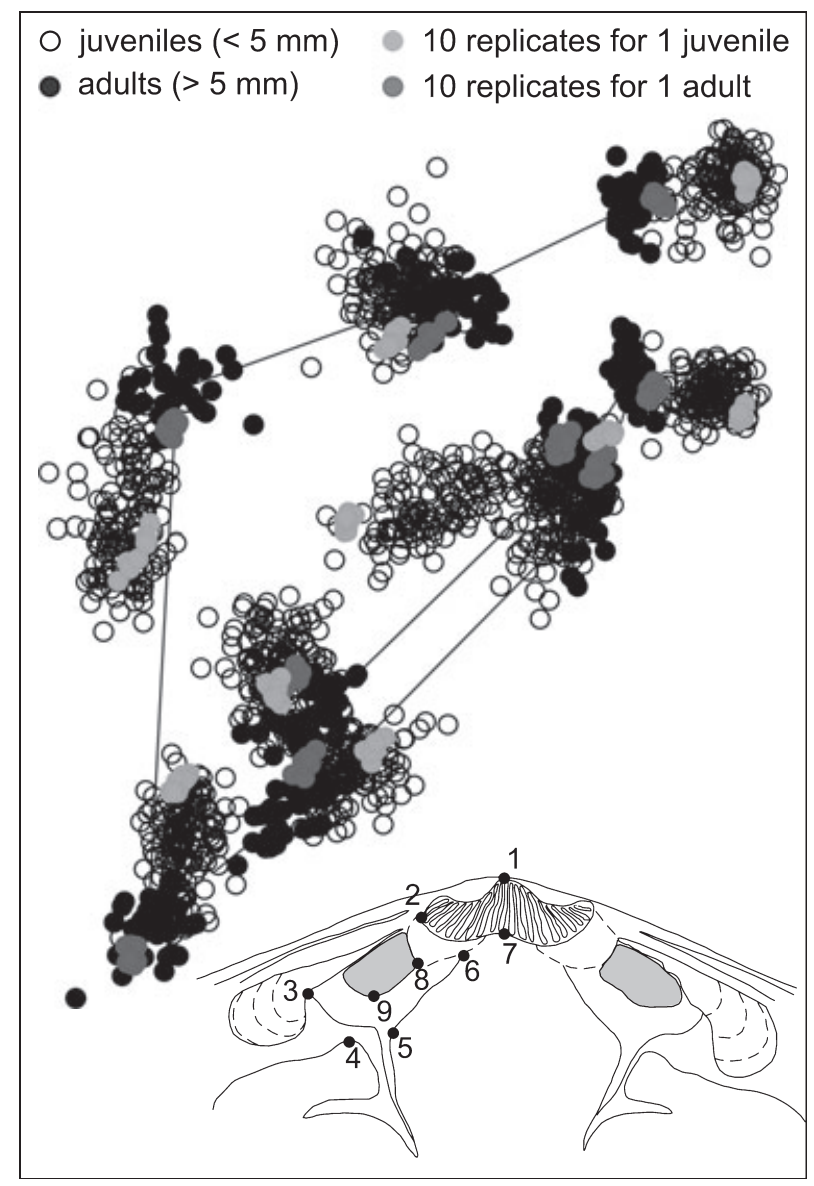

TEXT-FIG. 7. Landmark configurations of ten replicates of one juvenile $(<5 \mathrm{~mm})$ and one adult individual $(>5 \mathrm{~mm})$ showing measurement error associated with landmark digitizing. White (juveniles) and black points (adults) represent the full dataset of 189 individuals.
Ontogenetic shape changes between juveniles and adults are explored with the thin-plate spline method as deformation grids and plots showing vectors of landmark displacements (Webster et al. 2001; Kim et al. 2002). We use the Sliding Baseline Registration (SBR) superposition method in the thin-plate spline analyses because it is considered to be a biologically reasonable description of landmark variation in morphologies with an axis of symmetry (Webster et al. 2001). In order to test shape differences between size classes using the SBR method, we compute the Euclidean distance between the means of the compared size classes and perform a resampling test that determines an F-score (Zelditch et al. 2004). A bootstrap test, randomizing two size classes and resampling them with replacement, then estimates the probability that the observed F-score is larger than the bootstrapped F-score.

We quantify the allometry of cardinalia growth by exploring a degree of covariation between the natural log of centroid size and Procrustes distance from a reference configuration based on consensus of the three smallest individuals (Guralnick and Kurpius 2001; Webster 2007), and between the log centroid size and the first principal component axis (Roopnarine 2001). Regressed slopes of Procrustes distances and partial warp scores on log centroid size should be significantly different from zero under allometry. Under simple allometry, the amount of size-related shape change owing to allometry corresponds to the amount of variance explained by the regression.

Body size differences between crevices and flat substrates

To evaluate size differences of Terebratalia transversa populations between topographic lows (i.e. crevices) and flat surfaces (i.e. substrates with thinner benthic boundary layer, Vogel 1981, and higher detachment risk than crevices, Bourget et al. 1994; Walters and Wethey 1996), attachment sites of Terebratalia transversa individuals were recorded on boulders dredged in San Juan Channel (i.e. either a flat and elevated surface, or a crevice exceeding $5 \mathrm{~mm}$ in depth). Size is represented by dorsal valve length, the greatest anterior-posterior dimension.

\section{RESULTS}

Ontogeny of reorientation ability: observations vs. predictions

Based on cumulative observations of several dozen Terebratalia transversa individuals exposed to $1-2 \mathrm{~cm} / \mathrm{s}$ flow, Carlson (1983, 1987a, 1987b) found that juveniles smaller than $1 \mathrm{~mm}$, characterized by a trocholophe lophophore, reoriented by 180 degrees, juveniles $1-3 \mathrm{~mm}$ in 
length with a schizolophe lophophore showed a net rotation of about 20 degrees, and juveniles 3-5 $\mathrm{mm}$ in length with a zygolophe lophophore rotated very slightly by about 10 degrees (Table 2). Individuals larger than $5 \mathrm{~mm}$ in length did not show any reorientation.

Under a $10 \mathrm{~cm} / \mathrm{s}$ flow, individuals oriented with the anterior commissure downstream did not reorient after 24 hours. In contrast, several individuals with the anterior commissure initially oriented upstream reoriented to some degree. The initial orientation of attached juveniles changed because Modiolus reoriented rapidly after their placement in the flow chamber (Table 3). However, observations indicate that Terebratalia transversa individuals up to $3.5 \mathrm{~mm}$ in length can still reorient by 100 degrees and individuals $4 \mathrm{~mm}$ long can reorient by about 60 degrees. One individual reaching $8 \mathrm{~mm}$ in length reoriented by 25 degrees. Juveniles smaller than $5 \mathrm{~mm}$ show very high rotation angles, while subadult and adult individuals invariably do not reorient at all in the adult stage (lengths that exceed $10 \mathrm{~mm}$ ). Repeated observations of Thayer (1975) and LaBarbera (1977) also confirm that adult Terebratalia transversa individuals do not rotate. The observed cessation in reorientation of Terebratalia transversa takes place at a ventral valve length of about 5$8 \mathrm{~mm}$. The rate of decrease in the potential rotation angle is thus relatively rapid and coincides with the transition from schizolophe to zygolophe/plectolophe stage (Textfig. 6). Direct measurements of the angle $\alpha$ on shells with preserved soft tissues evaluate whether $2 \alpha$ is a good predictor of rotation ability of living brachiopods. The predicted $2 \alpha$ values show a good correspondence with the observed rotation angles of living individuals for juveniles and subadults (Text-fig. 6). The predicted net rotation angle $(2 \alpha)$ is about 160 degrees for juveniles $2 \mathrm{~mm}$ in length (Text-fig. 3A), about 130-140 degrees for juveniles reaching $4 \mathrm{~mm}$ in length (Text-fig. 3B), and 100-110 degrees for individuals $6 \mathrm{~mm}$ in length (Text-fig. 3C). However, net rotation angle should still attain about 20-25 degrees for adults $15-25 \mathrm{~mm}$ in length (Textfig. 3D-F). This predicted rotation angle clearly overestimates the observed rotation angle of zero exhibited by living adults (Text-fig. 6).

\section{Ontogeny of dorsal pedicle muscles and muscle scars}

Position of dorsal shell attachment points relative to the pedicle. The median attachment point of the dorsal pedicle muscles lies on the anteromedian sides of outer hinge plates that are slightly elevated above the floor of the dorsal valve in the juvenile stage (see arrows in Text-figs 3A$\mathrm{B}, 8 \mathrm{~A}-\mathrm{B})$. In contrast, in the subadult and adult stage, the

TA B LE 2. The observed net rotation angles of Terebratalia transversa under current velocity of $1-2 \mathrm{~cm} / \mathrm{s}$ (Carlson, 1983).

\begin{tabular}{|c|c|c|c|c|}
\hline Attachment substrate & $\begin{array}{l}\text { Lophophore } \\
\text { stage }\end{array}$ & $\begin{array}{l}\text { Current } \\
\text { velocity }(\mathrm{cm} / \mathrm{s})\end{array}$ & $\begin{array}{l}\text { Change after } \\
24 \text { hours (degrees) }\end{array}$ & $\begin{array}{l}\text { Ventral } \\
\text { valve length }\end{array}$ \\
\hline Terebratalia transversa & Early trocholophe & $1-2$ & $180-210$ & 0.3 \\
\hline Terebratalia transversa & Late trocholophe & $1-2$ & 180 & $0.3-1$ \\
\hline Terebratalia transversa & Schizolophe & $1-2$ & 20 & $1-3$ \\
\hline Terebratalia transversa & Zygolophe & $1-2$ & 10 & $3-5$ \\
\hline Terebratalia transversa & Early plectolophe & $1-2$ & 0 & $5-10$ \\
\hline
\end{tabular}

TABLE 3. Observed one-side rotation angles of Terebratalia transversa under current speed of $10 \mathrm{~cm} / \mathrm{s}$. One-side rotations should be doubled to estimate net rotation angles $(2 \alpha)$.

\begin{tabular}{|c|c|c|c|c|c|c|c|}
\hline Attachment substrate & Specimen ID & $\begin{array}{l}\text { Current } \\
\text { velocity } \\
(\mathrm{cm} / \mathrm{s})\end{array}$ & $\begin{array}{l}\text { Initial position - } \\
\text { exhalant current - } \\
\text { downstream } \\
\text { (degrees) }\end{array}$ & $\begin{array}{l}\text { Change } \\
\text { after } \\
24 \text { hours } \\
\text { (degrees) }\end{array}$ & $\begin{array}{l}\text { Initial position - } \\
\text { exhalant current - } \\
\text { upstream } \\
\text { (degree) }\end{array}$ & $\begin{array}{l}\text { Change } \\
\text { after } \\
24 \text { hours } \\
\text { (degrees) }\end{array}$ & $\begin{array}{l}\text { Ventral } \\
\text { valve } \\
\text { length }\end{array}$ \\
\hline Modiolus modiolus \#1 & Terebratalia transversa \#1 & 10 & 13 & 0 & 8 & 0 & 3.4 \\
\hline Modiolus modiolus \#1 & Terebratalia transversa \#2 & 10 & 13 & 0 & 8 & 41 & 0.92 \\
\hline Modiolus modiolus \#2 & Terebratalia transversa \#3 & 10 & 18 & 0 & 108 & 46 & 1.85 \\
\hline Modiolus modiolus \#3 & Terebratalia transversa \#4 & 10 & 0 & 0 & 165 & 0 & 3.2 \\
\hline Modiolus modiolus \#4 & Terebratalia transversa \#5 & 10 & 0 & 0 & 115 & 0 & 3.6 \\
\hline Modiolus modiolus \#5 & Terebratalia transversa \#6 & 10 & 0 & 0 & 35 & 25 & 8.4 \\
\hline Modiolus modiolus \#6 & Terebratalia transversa \#8 & 10 & 47 & 0 & 78 & 31 & 4.2 \\
\hline Modiolus modiolus \#6 & Terebratalia transversa \#9 & 10 & 50 & 0 & 115 & 50 & 3.6 \\
\hline Modiolus modiolus \#6 & Terebratalia transversa \#10 & 10 & 29 & 0 & 22 & 57 & 1.62 \\
\hline
\end{tabular}


outer hinge plates are not only substantially elevated above the dorsal valve floor (Text-fig. 8C-D), but are also elevated above the commissural plane (Text-fig. 3F).

A horizontal change in the position of the dorsal attachment point with respect to the valve midline is measured as an ontogenetic change in horizontal distance between the dorsal pedicle muscle scars (i.e. between-scar distance, Text-fig. 8). The between-scar distance increases with a very strong positive allometry with increasing centroid size (Text-fig. 9A, LSR slope $=1.93, \quad 95 \%$ $\mathrm{CI}=1.87-1.99)$. The distance between adjustor muscles becomes relatively larger than the length of the dorsal valve with growth $(\mathrm{RMA}$ slope $=1.65 ; 95 \% \mathrm{CI}=1.6-$ 1.7). Dorsal attachment points of dorsal pedicle muscles thus rise above the valve floor (Text-fig. $3 \mathrm{~A}$ vs. Textfig. 3F) and allometrically shift away from the valve midline (Text-fig. 9A).

However, the estimated slopes from linear regressions are affected by curvilinearity. The locally-weighted poly- nomial regression shows the break in the fitted line at length of about $7.5 \mathrm{~mm}$ (Text-fig. 9A), and residuals of the between-scar distance from linear regressions show highly non-linear variations around zero, with negative values at small and large sizes, and positive values at intermediate stages (Text-fig. 9B). The rate of increase of the between-scar distance with respect to centroid size in juveniles $(<5 \mathrm{~mm}, \quad$ LSR slope $=2.24,95 \% \quad \mathrm{CI}=1.98$ 2.46) is significantly higher than the rate of increase of the between-scar distance in adults $(>5 \mathrm{~mm}$, LSR slope $=1.57,95 \% \mathrm{CI}=1.47-1.66)$. The F-value indicates that the quadratic regression explains growth variations in between-scar distance significantly better than the simple linear regression (Table 4).

Position of ventral attachment points relative to the pedicle bulb. The attachment sites to the pedicle are situated approximately on the lateral sides of the pedicle in the juvenile stage, and remain in this position or are slightly
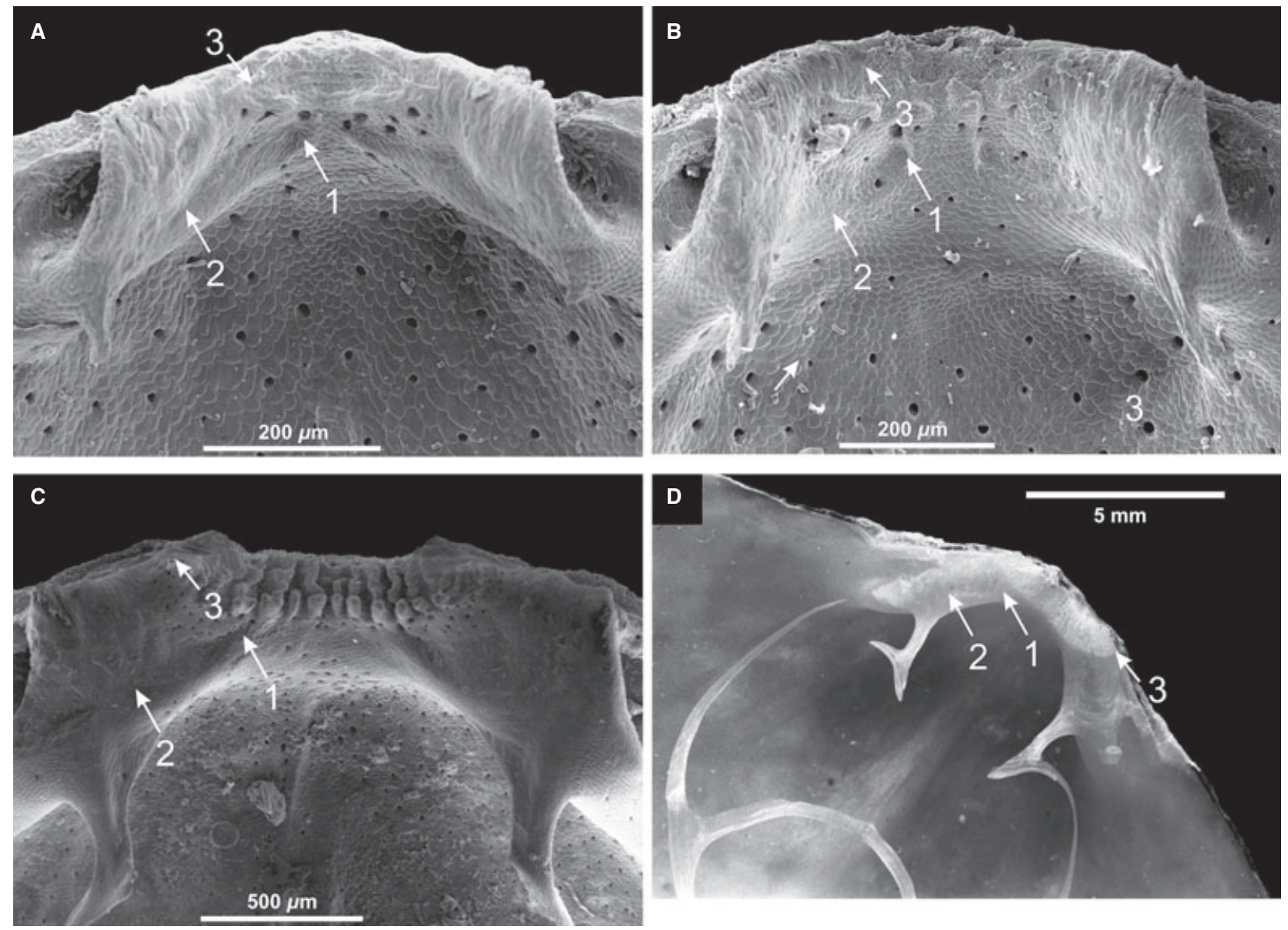

TEXT-FIG. 8. Ontogenetic increase in the distance between posteromedian parts of dorsal pedicle muscles scars (arrow 1), and ontogenetic increase in the width of the cardinal process in Terebratalia transversa. Anterolateral parts of dorsal pedicle muscle scars are marked with arrow 2. Lateral parts of the cardinal process are marked with arrow 3. A, Dorsal valve length is $1.06 \mathrm{~mm}$. B, Dorsal valve length is $1.2 \mathrm{~mm}$. C, Dorsal valve length is $4.9 \mathrm{~mm}$. D, Dorsal valve length is $19.1 \mathrm{~mm}$. Figures A-C were obtained using a scanning electron microscope and figure $\mathrm{D}$ was photographed under a light microscope. 

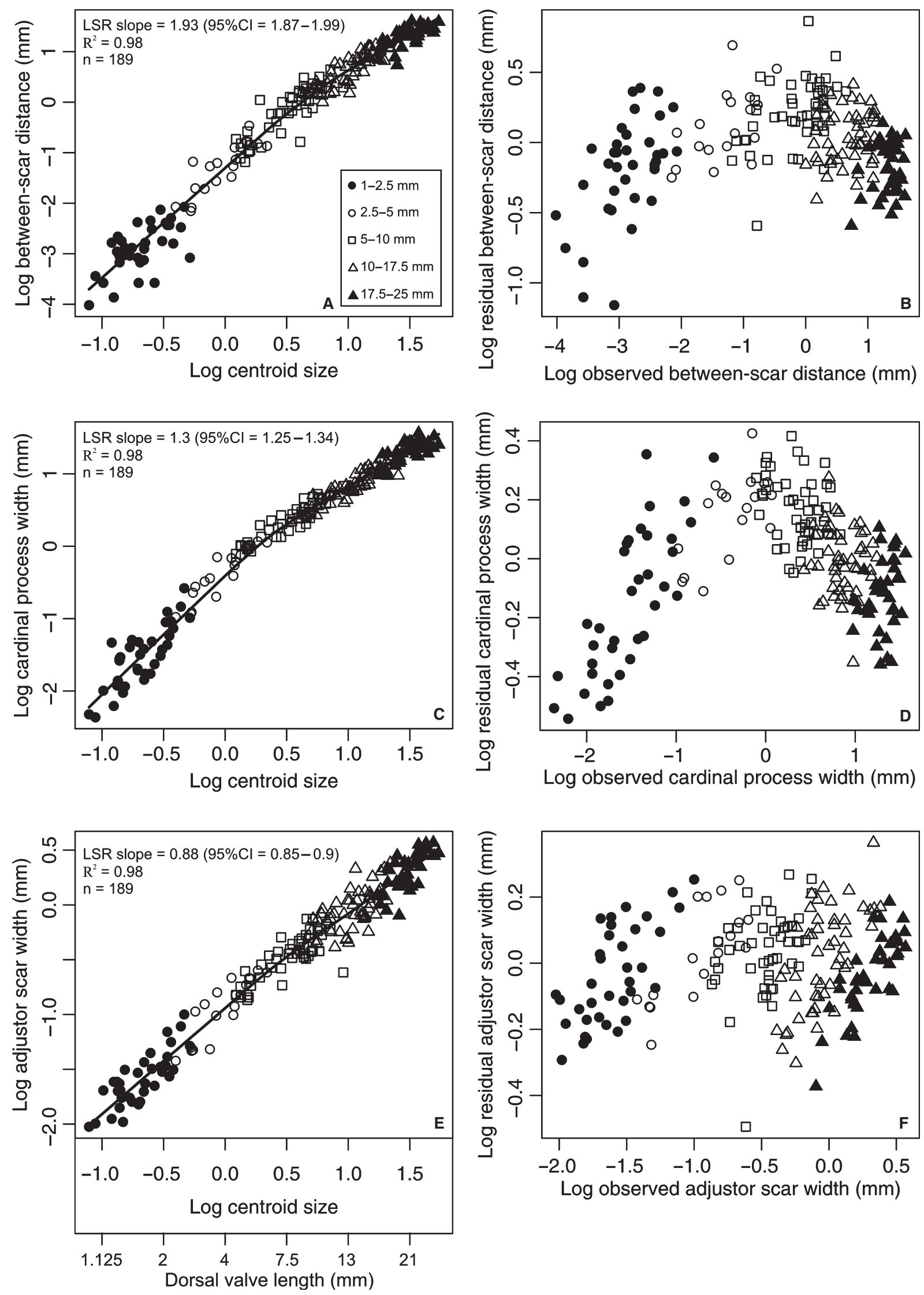
TABLE 4. Pearson correlations between principal components and 15 morphological traits, univariate (based on least-square regressions of log-transformed traits on log centroid size) and multivariate allometric coefficients (the PC1 loading of each trait divided by the mean PC1 loading over all traits), and results of the F-test for complex allometry in 15 morphological traits of Terebratalia transversa. Allometric coefficents in boldface refer to means whose $95 \%$ bootstrapped confidence intervals did not overlap with 1 . The $p$-values in boldface are results that are significant after sequential Bonferroni correction at $\alpha=0.05$.

\begin{tabular}{|c|c|c|c|c|c|c|c|}
\hline Shell trait & $\begin{array}{l}\text { Correlation } \\
\text { between PC1 } \\
\text { and trait }\end{array}$ & $\begin{array}{l}\text { Correlation } \\
\text { between PC2 } \\
\text { and trait }\end{array}$ & $\begin{array}{l}\text { Univariate } \\
\text { allometric } \\
\text { coefficient - } \\
\text { juvenile }(<5 \mathrm{~mm})\end{array}$ & $\begin{array}{l}\text { Univariate } \\
\text { allometric } \\
\text { coefficient - } \\
\text { adult }(>5 \mathrm{~mm})\end{array}$ & $\begin{array}{l}\text { Multivariate } \\
\text { allometric } \\
\text { coefficient }\end{array}$ & F-value & $\mathrm{p}$ \\
\hline Dorsal valve length & 0.991 & 0.036 & 1.21 & 1.01 & 0.98 & 48.82 & $<0.0001$ \\
\hline Dorsal valve width & 0.992 & -0.005 & 1.41 & 1.05 & 1.03 & 92.42 & $<0.0001$ \\
\hline Shell thickness & 0.991 & 0.055 & 1.34 & 1.28 & 1.16 & 4.24 & 0.041 \\
\hline Pedicle opening diameter & 0.988 & 0.032 & 1.19 & 1.13 & 0.99 & 0.28 & 0.597 \\
\hline Cardinalia width & 0.994 & 0.056 & 1.2 & 1.14 & 0.98 & 0.32 & 0.57 \\
\hline Cardinalia length & 0.982 & 0.137 & 1.08 & 1.04 & 0.90 & 4.49 & 0.036 \\
\hline Outer hinge plate length & 0.994 & 0.047 & 1.2 & 1.13 & 1.03 & 15.6 & 0.0001 \\
\hline Outer hinge plate width & 0.969 & 0.150 & 0.98 & 0.99 & 0.80 & 10.4 & 0.0014 \\
\hline Between-crural distance & 0.987 & 0.047 & 1.05 & 0.98 & 0.83 & 1.82 & 0.18 \\
\hline Between-plate distance & 0.967 & -0.225 & 2.29 & 1.13 & 1.30 & 136.1 & $<0.0001$ \\
\hline Adjustor scar length & 0.949 & 0.228 & 0.84 & 0.86 & 0.71 & 3.61 & 0.059 \\
\hline Cardinal process width & 0.991 & -0.033 & 1.75 & 0.99 & 0.98 & 163.8 & $<0.0001$ \\
\hline Cardinal process length & 0.983 & 0.088 & 1.28 & 1.17 & 1.03 & 5.44 & 0.021 \\
\hline Between-scar distance & 0.986 & -0.140 & 2.24 & 1.57 & 1.57 & 61.84 & $<0.0001$ \\
\hline Adjustor scar width & 0.959 & 0.142 & 0.98 & 0.79 & 0.71 & 11.48 & 0.0009 \\
\hline
\end{tabular}

shifted in the ventral direction in the adult stage (Textfig. 3). The dorsal pedicle muscles are attached to the pedicle epithelium in juveniles, but insertions extend into the fibrous connective tissue in adults of Terebratalia transversa (Stricker and Reed 1985). Although the connection between the attachment points and the pedicle in the juvenile stage is not completely visible in anterior views (Text-fig. 3), the ventral insertions probably also do not change markedly in size during ontogeny. The width of pedicle opening diameter increases with a very slight but significantly positive allometry with increasing centroid size (Text-fig. 10, LSR slope $=1.14,95 \% \mathrm{CI}=1.12-1.17)$. Its growth is almost isometric relative to dorsal valve length (RMA slope $=0.97,95 \%$ CI $=0.95-0.997)$, and the locallyweighted polynomial regression shows a relatively linear fit (Text-fig. 10). Residuals of the pedicle opening diameter width from linear regressions show a relatively random variation around zero (Text-fig. 10). The rate of increase of pedicle opening diameter also does not differ between juveniles and adults, and the F-value is very low (Table 4).
Cardinal process width. The cardinal process is formed by a transversely oval depression in the juvenile stage (Text-fig. 8A-B). In the adult stage, it is formed by an elevation or raised ridge consisting of parallel, highly irregular ridges, with lateral margins being curved in the posterior direction (Text-fig. 8C). The width of the muscle attachment site of the cardinal process changes with a significantly positive allometry with respect to centroid size (Text-fig. 9C, LSR $=1.3,95 \% \mathrm{CI}=1.25-1.34$ ), and dorsal valve length (RMA slope $=1.11,95 \% \mathrm{CI}=1.07$ $1.14)$.

The locally-weighted polynomial regression shows a break in the fitted line at length of about $5 \mathrm{~mm}$ (Textfig. 9C). Non-linear residuals of the cardinal process width from linear regressions show a rather sharp break that corresponds to the dorsal valve length of 3-5 mm (Text-fig. 9D). Cardinal process width grows with a positive allometry in juveniles (Text-fig. 11, LSR slope $=1.75$, $95 \% \mathrm{CI}=1.6-1.88)$, and grows isometrically in adults (LSR slope $=0.99,95 \% \mathrm{CI}=0.95-1.03)$. The complex allometry is also demonstrated by the high and significant F-value (Table 4).

TEXT-FIG. 9. Curvilinear bivariate relationships between centroid size (based on landmark configuration in Text-fig. 3B) and between-scar distance (A), between centroid size and cardinal process width (C), and between centroid size and adjustor scar width (E). The fitted lines are based on the locally-weighted polynomial regressions. The residuals from bivariate linear regressions show curved patterns and demonstrate that complex allometric changes take place at centroid size corresponding to $3-7 \mathrm{~mm}$ long dorsal valves $(\mathrm{B}, \mathrm{D}, \mathrm{F})$. 

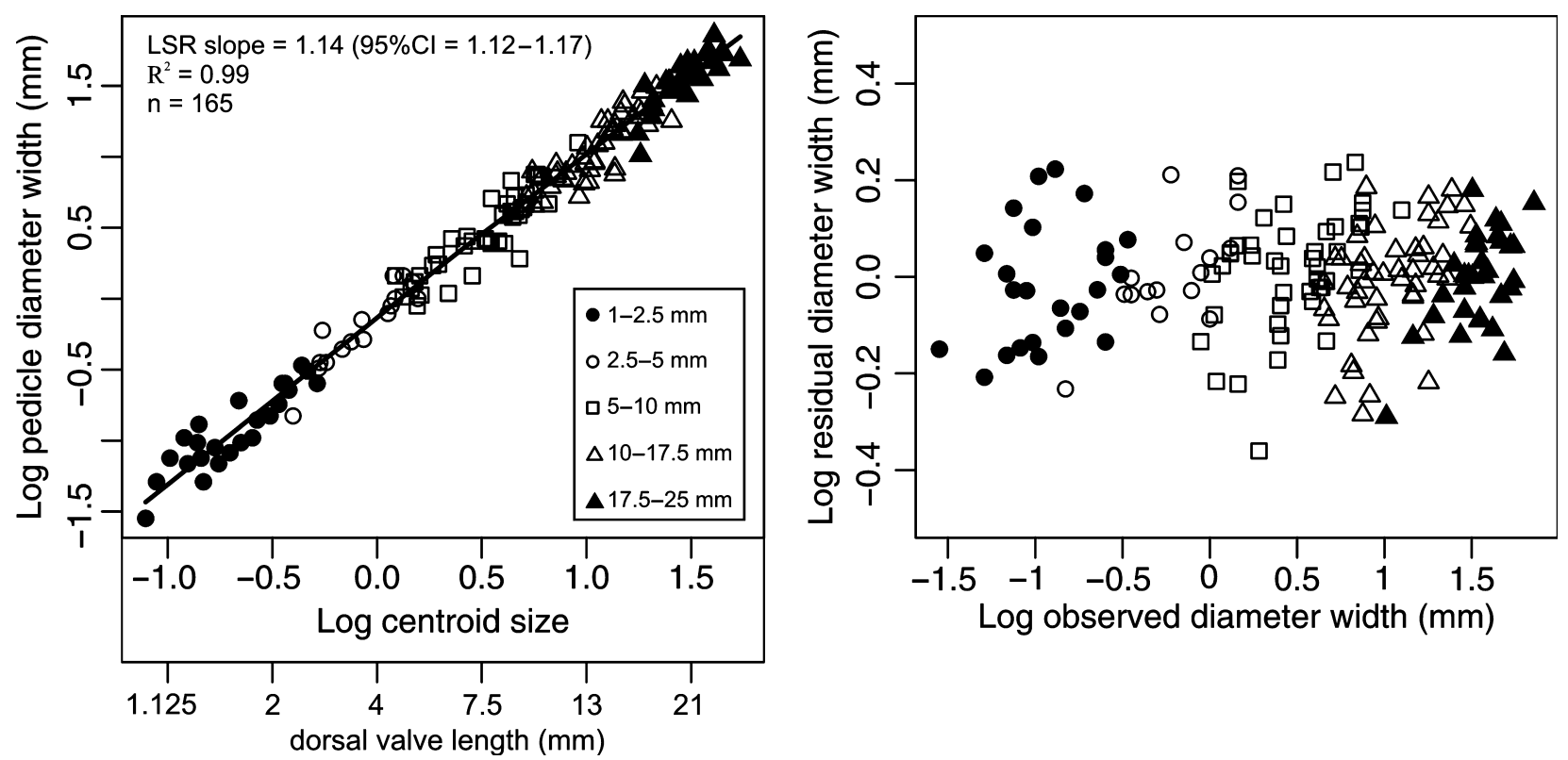

TEXT-FIG. 10. Bivariate relationship between pedicle opening diameter and centroid size is relatively linear (the fitted line is based on the locally-weighted polynomial regression), and the residuals of the pedicle diameter from linear regression are randomly distributed around zero.
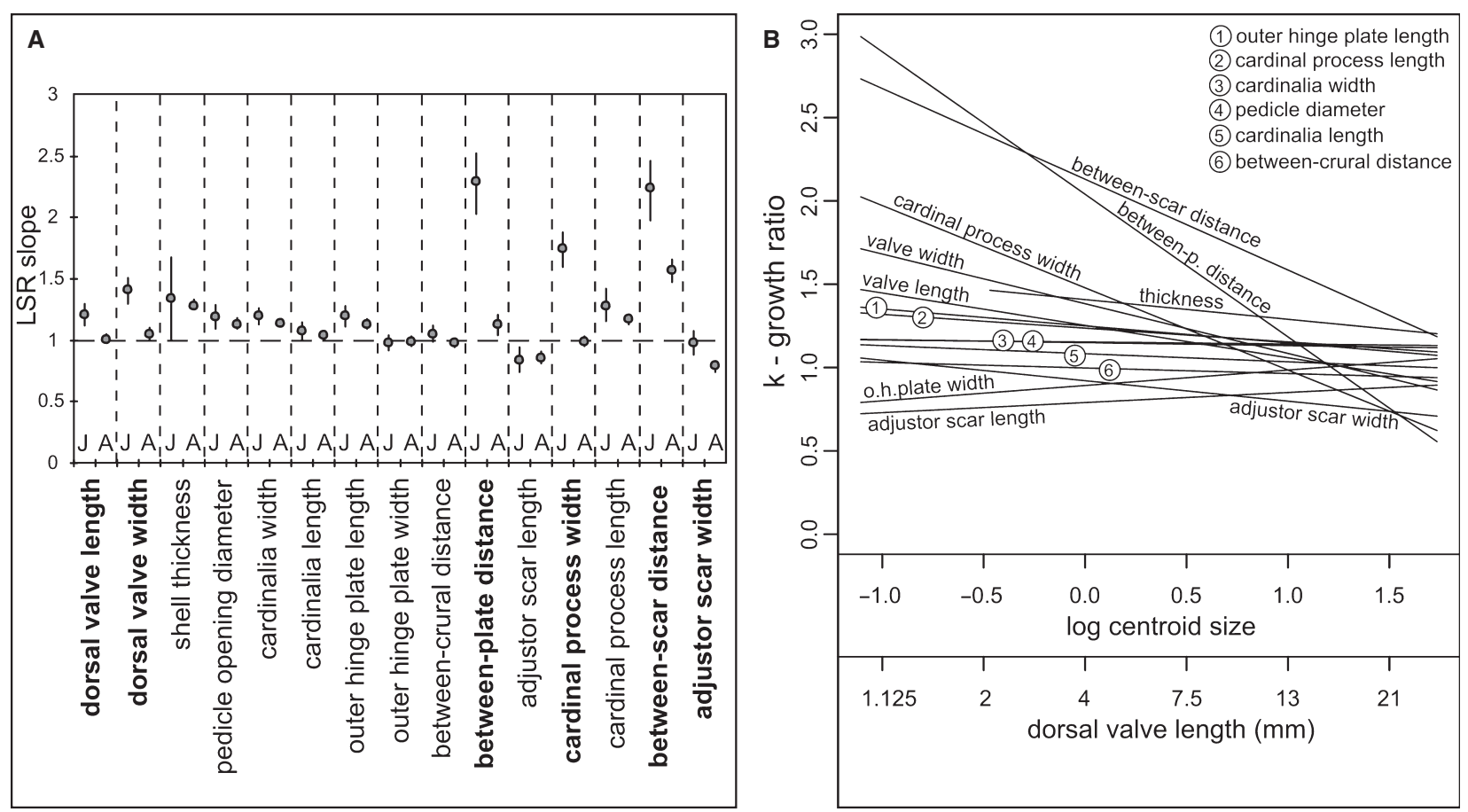

TEXT-FIG. 11. A, Based on $95 \%$ bootstrapped confidence intervals, juveniles (,$<5 \mathrm{~mm}$ ) and subadults and adults (A, $>5 \mathrm{~mm})$ significantly differ in allometric coefficients of morphological traits that are related to the attachment of dorsal pedicle muscles (allometric coefficients are based on least-square linear regressions). Traits showing significant differences between juveniles and adults, i.e., traits that do not show their mean within the $95 \%$ confidence interval of the other mean, are in bold. B, Size-related ontogenetic changes in allometric coefficients (growth ratios - first derivatives of the second-order polynomial fits) also show that traits related to the attachment of dorsal pedicle muscles are characterized by the strongest ontogenetic changes (e.g. between-plate distance, betweenscar distance, and cardinal process width). 
Outline of the pedicle bulb. In the smallest individuals, ventral insertions of dorsal pedicle muscles and dorsal insertions of ventral pedicle muscles penetrate or are continuous with an epithelium that separates the pedicle from the body cavity (Text-fig. 3A-B, see also Stricker and Reed 1985). The pedicle bulb is transversely elongated in the adult stage, mainly because the cardinal process is highly elevated above the commissure (Textfig. 3E). This general change towards an elongate pedicle bulb can also contribute to the decrease in the angle $\alpha$ during ontogeny of $T$. transversa.

Size of dorsal pedicle muscle scars. The width of adjustor scars shows a negative allometry with respect to centroid size (Text-fig. 9E, LSR slope $=0.88,95 \%$ CI $=0.85-0.9$ ). The scar width becomes relatively smaller than the length of the dorsal valve with growth (RMA slope $=0.75 ; 95 \%$ $\mathrm{CI}=0.73-0.77)$. The locally-weighted polynomial regression shows a slight break in the fitted line at length between 4-7 mm (Text-fig. 9E). Residuals of the adjustor scar width from linear regressions are also non-linear, with the breakpoint occurring at the length of dorsal valve of about $5 \mathrm{~mm}$ (Text-fig. 9F). The rate of decrease of the adjustor scar width is significantly lower and isometric in juveniles (Text-fig. 11A, LSR slope $=0.98,95 \%$ $\mathrm{CI}=0.88-1.08)$ than in adults (LSR slope $=0.79,95 \%$ $\mathrm{CI}=0.74-0.83)$, and F-test confirm complex allometric growth of the scar width (Table 4 ).

\section{Ontogeny of cardinalia}

Traditional morphometric analyses. Bivariate analyses with the log-transformed centroid size as an independent variable and morphological traits other than adjustor scars as dependent variables show that shell length, width, and thickness, cardinalia width, outer hinge plate length, and cardinal process length and width change with a significantly positive allometry. Cardinalia length show a slight positive allometry (LSR slope $=1.07$, 95\% CI $=1.05-$ 1.08), and outer hinge plate width grows with a slight negative allometry with centroid size (LSR slope $=0.93$, 95\% CI $=0.91-0.95)$. The between-crural distance increases isometrically (LSR slope $=0.99,95 \% \mathrm{CI}=0.97-$ 1). The between-plate distance shows a similarly high negative allometry as the between-scar distance (LSR slope $=1.72$ ). Significant differences in regression coefficients between juveniles and adults characterize the cardinal process and position of the pedicle muscle scars (Text-fig. 11A, Table 4). A curvilinear trajectory in shape change is shown by a significant improvement in the F-value based on the second-order polynomial for several traits (Table 4). In addition to the changing growth ratios of the between-scar distance and the cardinal process width, substantial changes in growth ratio characterize the between-plate distance (Text-fig. 11B). Allometric growth rates invariably decrease with increasing centroid size. This complex allometry is localized and characterizes only those parts of cardinalia that are related to diductor and pedicle muscle scars.

In multivariate analysis, PC1 accounts for $>96 \%$ of the variation in the principal component analysis based on the 15 log-transformed morphological variables. All shell traits show a very high correlation with PC1 $(r>0.98$, Table 4) and the five a priori-defined size classes are well demarcated along PC1 (Text-fig. 12). Thus most of the morphological variation can be explained by size and size-related shape variation that is related to PC1. The pattern of morphological variation is non-linear along the second PC (1.45\%), with the smallest and largest size classes being characterized by more negative values than intermediate size classes. The loadings on PC2 and correlations between shell traits and PC2 show that the differences along this component are mainly driven by variations in traits that are related to shape and position of dorsal pedicle muscle scars (Text-fig. 12, Table 4). These variables include between-plate distance, adjustor scar length, and between-scar distance.

Multivariate allometric analyses similarly show that the highest allometric coefficients incorporate variables related to dorsal pedicle muscle scars (Text-fig. 12, Table 4). Between-scar distance and between-plate distance show a highly positive allometry, and adjustor scar width and length show a highly negative allometry. The relationships between shell traits and PC2 and the multivariate coefficients thus show that ontogenetic changes in size and shape of adjustor scars drive this non-linear pattern (Table 4). Note that the non-linearity of the multivariate pattern probably obscures allometric growth of other traits such as the cardinal process width because the coefficients are based on a linear model.

Landmark-based analyses. The univariate approach regressing Procrustes distances on log-transformed centroid size (slope $=0.126$, std $=0.005, \quad Z$-score $=19.29, \quad r=0.89$ ), and the multivariate approach regressing all shape variables (i.e. components of the uniform deformation and partial warp scores) against log-transformed centroid size (Wilks Lambda $=0.106, \quad$ F-score $=105.08, \quad \%$ variance explained $=0.89, \mathrm{df} 1=14, \mathrm{df} 2=174, P<0.0001)$ reveal a significantly allometric growth of cardinalia (Textfig. 13). Allometric shape change accounts for the majority of ontogenetic variation in cardinalia morphology (89\%). Principal component analysis based on partial warp scores derived from Procrustes superposition shows distinct differences among the five size classes along PC1 

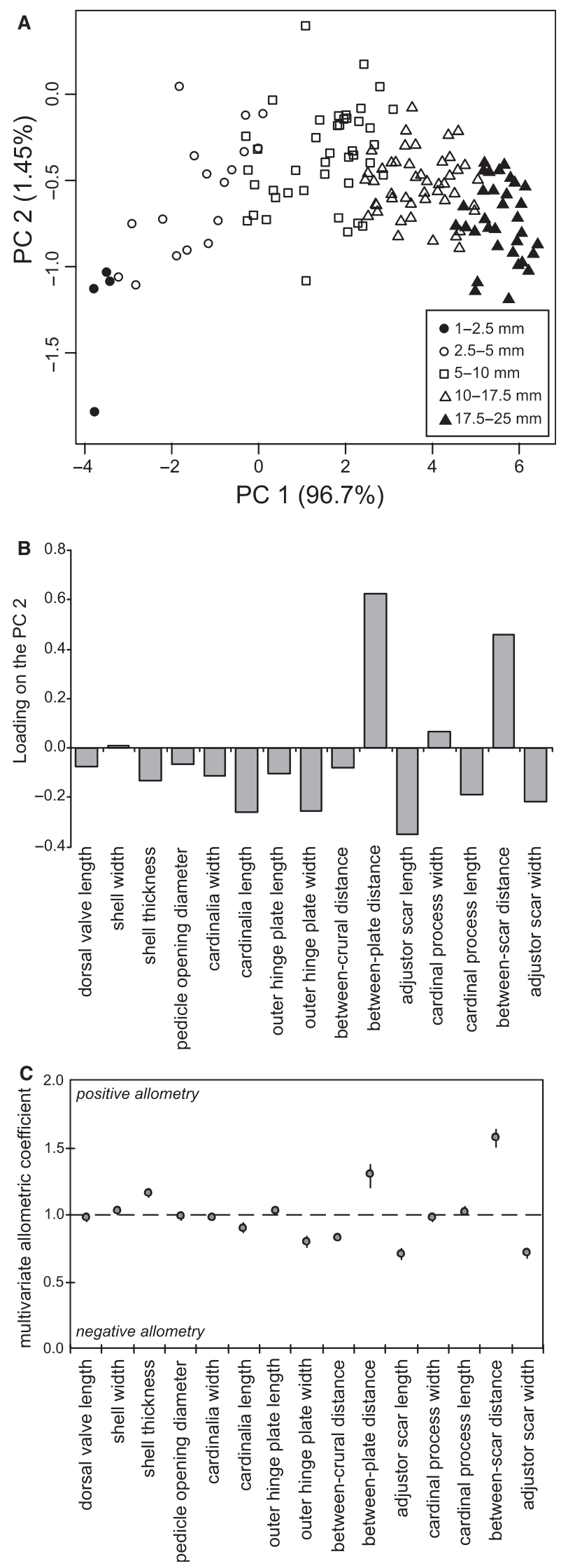

(62.5\%). It shows a curved, non-linear pattern of landmark configurations along PC1 (Text-fig. 14A), with the a priori size classes being related not only to $\mathrm{PCl}$, but also to PC2 (9.1\%). We note that landmark configurations are rescaled to unit centroid size in Procrustes and SBR superpositions. Therefore, size differences are factored out and differences among size classes observed in landmark-based PCA are thus not related to differences in specimen size (as in traditional PCA based on distances). However, variations in landmark configurations in PCA clearly show that cardinalia shape does change as a function of size.

Canonical variate analysis shows that the five size classes are significantly different in shape (Text-fig. 14B), with the first three axes being significant and thus discriminating among the five groups (CVA1: $\Lambda=0.049$, $\chi^{2}=538.89, \mathrm{df}=56, P<0.0001, \mathrm{CVA} 2: \Lambda=0.408, \chi^{2}=$ $160.18, \mathrm{df}=39, \mathrm{p}<0.0001, \mathrm{CVA3}: \Lambda=0.797, \chi^{2}=40.45$, $\mathrm{df}=24, P=0.0004)$. Comparisons of changes in landmark configurations among size classes in SBR show substantial ontogenetic variations in the shape of the cardinalia. Based on SBR superposition, pairwise comparisons show significant differences in mean shape among five size groups (bootstrapped F-test). The Euclidean distance between successive means substantially decreases with increasing size. It is relatively high between the first and second size class (F-score $=19.6$, distance between means $=0.216,95 \% \mathrm{CI}=0.17-0.26$ ), and between the second and third size class (F-score $=18.5, \mathrm{~d}=0.214$, $95 \% \mathrm{CI}=0.18-0.26)$. In contrast, it is markedly lower between the third and fourth size class (F-score $=12.3$, $\mathrm{d}=0.098,95 \% \mathrm{CI}=0.07-0.14)$, and between the fourth and fifth size class (F-score $=7.05, \quad d=0.089, \quad 95 \%$ $\mathrm{CI}=0.06-0.13)$. The thin-plate spline showing deformation of the largest individual from the three smallest individuals, visualized by vectors of landmark displacement and deformation grid, indicates pronounced morphological changes in cardinalia shape (Text-fig. 14C, D). The major changes are a shift of the median boundary of adjustor scars away from the midline, widening of the cardinal process, and widening and shortening of outer hinge plates and inner socket ridges.

TEXT-FIG. 12. A, Principal component analysis of 144 individuals based on 15 morphological traits. The eigenvalues are $\mathrm{PC} 1=6.4[96.7 \%], \mathrm{PC} 2=0.1[1.45 \%], \mathrm{PC} 3=0.03[0.44 \%]$, PC4 $=0.02[0.28 \%]$. B, Morphological traits related to the attachment of dorsal pedicle muscles predominantly contribute to loadings on PC2. C, Multivariate allometric coefficients with 95\% bootstrapped confidence intervals, based on PCA, show that the significantly negative allometry is exhibited by the size of adjustor scars and the significantly positive allometry by distance between adjustor scars. 

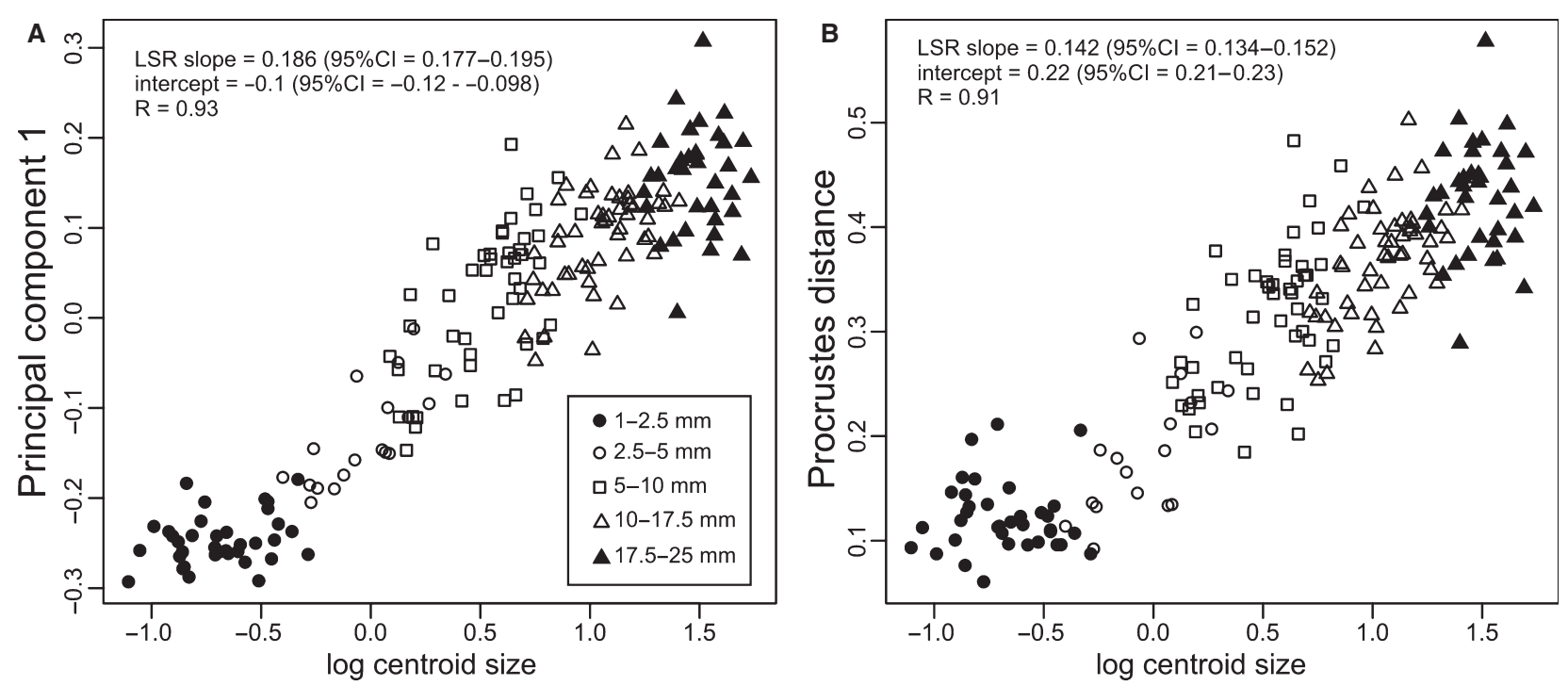

TEXT-FIG. 13. Landmark-based analyses show a significantly allometric growth of cardinalia of Terebratalia transversa. A, Scores from the PC1 (PCA based on the partial warp scores derived from the Procrustes superposition and a GLS Procrustes mean reference specimen based on all individuals) regressed on the natural log of centroid size. B, Rate of cardinalia shape change relative to the natural log of centroid size, based on partial Procrustes distance from a reference form based on consensus of the three smallest individuals.

Thin-plate splines performed separately for the five size classes reveal the pattern and magnitude of ontogenetic shape changes in cardinalia (Text-fig. 15). First, the most pronounced shape change is restricted to two size classes that attain $2.5-10 \mathrm{~mm}$. The retreat of adjustor scars and outer hinge plates from the midline, and the rapid widening of the cardinal process are the most evident changes visible in displacement and deformation plots (Text-fig. 15). These traits thus grow faster than other traits in the juvenile $(2.5-5 \mathrm{~mm})$ and subadult stages $(5-10 \mathrm{~mm})$. Note that the widening of the cardinal process is limited to stages attaining $2.5-5 \mathrm{~mm}$. Second, the change in cardinalia shape slows down at stages exceeding $10 \mathrm{~mm}$ in length when allometric widening of cardinal process and between-plate distance stops. Third, the direction of shape change in most traits can reverse at stages exceeding a dorsal valve length of $17.5 \mathrm{~mm}$. The lengths of the vectors of landmark displacement (Text-fig. 15) demonstrate that the ontogenetic trajectory is characterized by decreasing magnitude of allometric change of shape of adjustor scars, outer hinge plates, and cardinal process width. The transition between individuals $2.5-10 \mathrm{~mm}$ in length corresponds to a major shape change. Similar to analyses based on traditional morphometric variables, landmarkbased analyses thus show that (1) cardinalia shape changes are mainly restricted to juvenile stages, and that (2) they correspond to those portions of the cardinalia that affect the rotation and the torque during the opening of valves.
Size differences between crevices and flat substrates

There are significant differences in median length between Terebratalia transversa populations occupying crevices and flat substrates, with populations in crevices showing smaller median length (Wilcoxon rank-sum test, $\mathrm{p}=$ 0.0062). This effect of substrate rugosity is also significant when only individuals larger than $5 \mathrm{~mm}$ are evaluated (Wilcoxon rank-sum test, $\mathrm{p}=0.0037$ ). This effect becomes reduced when individuals larger than $10 \mathrm{~mm}$ are evaluated (Wilcoxon rank-sum test, $\mathrm{p}=0.09$ ), and disappears when individuals larger than $15 \mathrm{~mm}$ are evaluated (Wilcoxon rank-sum test, $\mathrm{p}=0.67$ ). Therefore, the difference in median length is related to the higher proportions of small individuals in crevices; large individuals do not differ in median length between crevices and flat surfaces.

\section{DISCUSSION}

\section{Ontogenetic niche shift}

Non-linear residuals of between-scar distance and cardinal process width based on linear regressions, higher allometric coefficients of these traits in juveniles than in adults, and ontogenetic decrease in their growth ratios based on polynomial regressions, demonstrate that the allometric change is curvilinear, with a marked allometric change at a dorsal valve length of $2.5-10 \mathrm{~mm}$. Landmark analyses show that the growth 

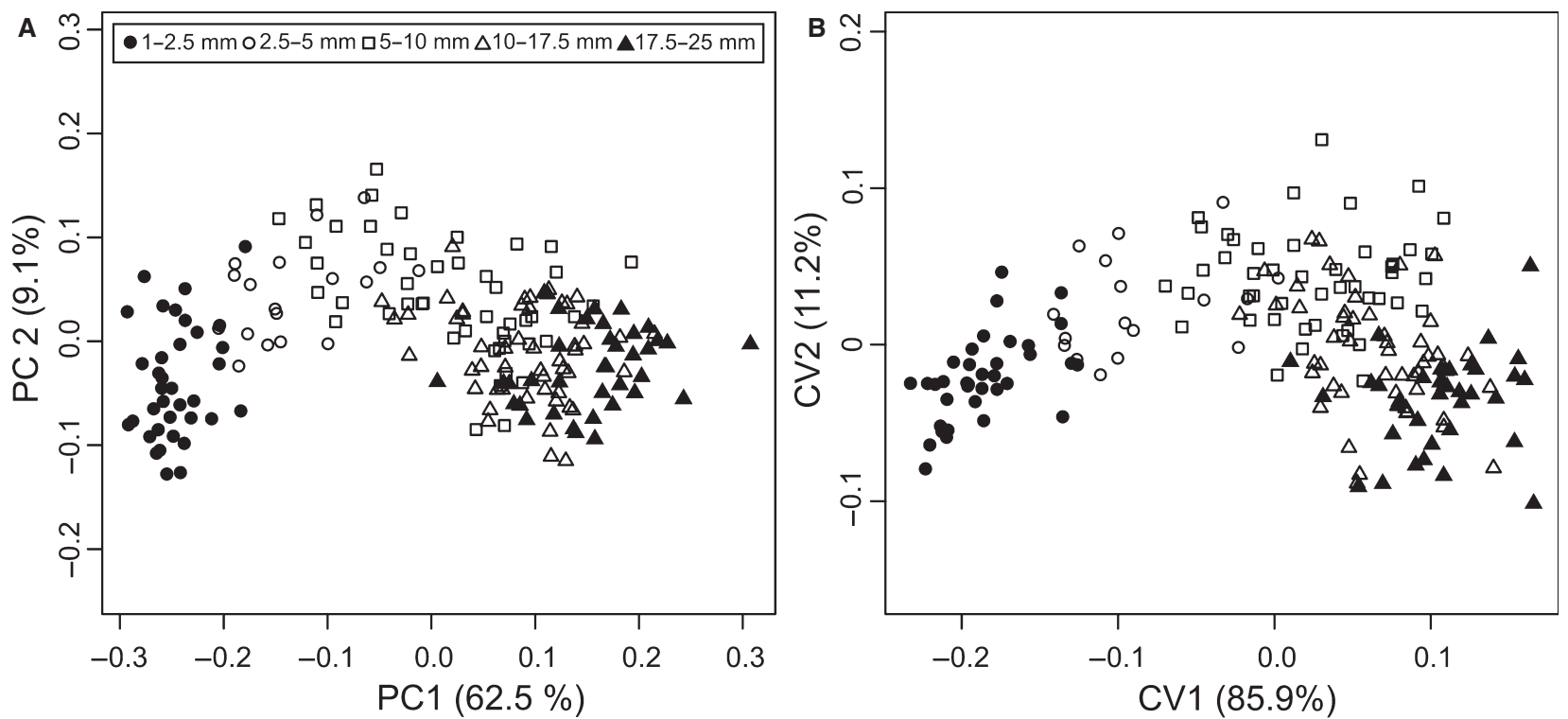

C

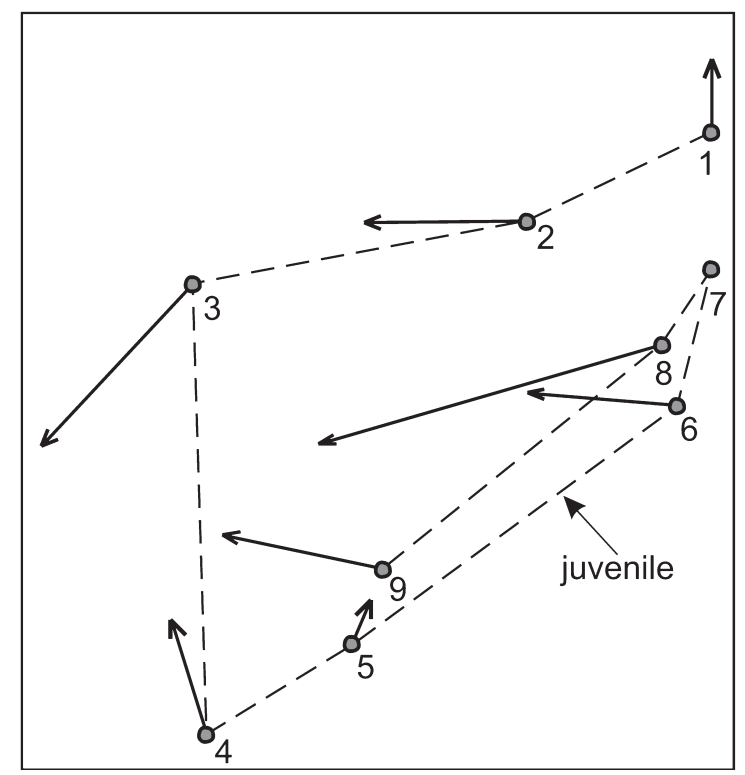

D

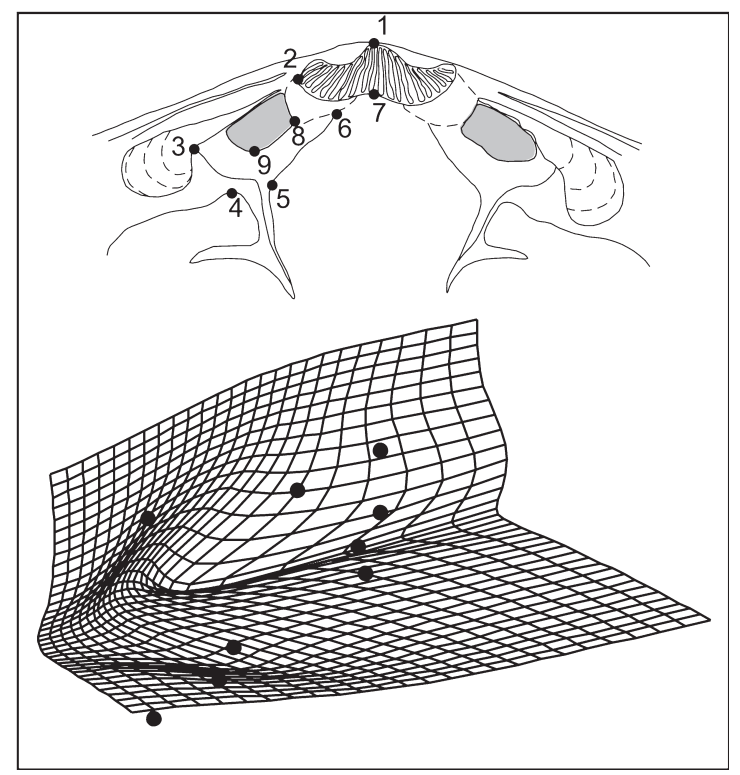

TEXT-FIG. 14. A, A scatter plot of the PCA axes scores of 189 individuals, based on the partial warp scores derived from the Procrustes superposition and a GLS Procrustes mean reference specimen based on all individuals. The eigenvalues are PC1 $=0.024$ [62.5\%], PC2 $=0.0034[9.1 \%]$, PC3 $=0.0023[6 \%]$, PC4 $=0.0018[4.8 \%]$. B, Significant separation of cardinalia of five size classes on the first two axes of CVA, based on the partial warp scores. C, Vectors of landmark displacement show the shape change from the three smallest juveniles (reference form) to the largest individual, based on the regression of the partial warp scores on the log centroid size and Sliding Baseline Registration superposition. They show that one of the most pronounced ontogenetic changes is related to the lateral shift of posteromedian attachment point of dorsal pedicle muscles (point 8 ). D, Deformation grid visualizing shape change from the three smallest juveniles (reference form) to the largest individual, based on the regression of the partial warp scores on the natural log of centroid size and Sliding Baseline Registration superposition.

change is fast for small lengths and slows down at a length exceeding $10 \mathrm{~mm}$, and also demonstrate that allometric changes related to shape of cardinal process and adjustor scars are the dominant source of variation in the whole cardinalia shape. Although non-linear allometric trajectories of morphological traits can be expected in brachiopods owing to their complex onto- genetic changes in lophophore configuration (e.g. Mackay et al. 1993; MacKinnon et al. 1997), we show that non-linear allometric growth also substantially affects the shape of morphological traits related to the pedicle and diductor muscles in Terebratalia transversa. Although allometric growth can be a consequence of maintenance of function over a size range (LaBarbera 

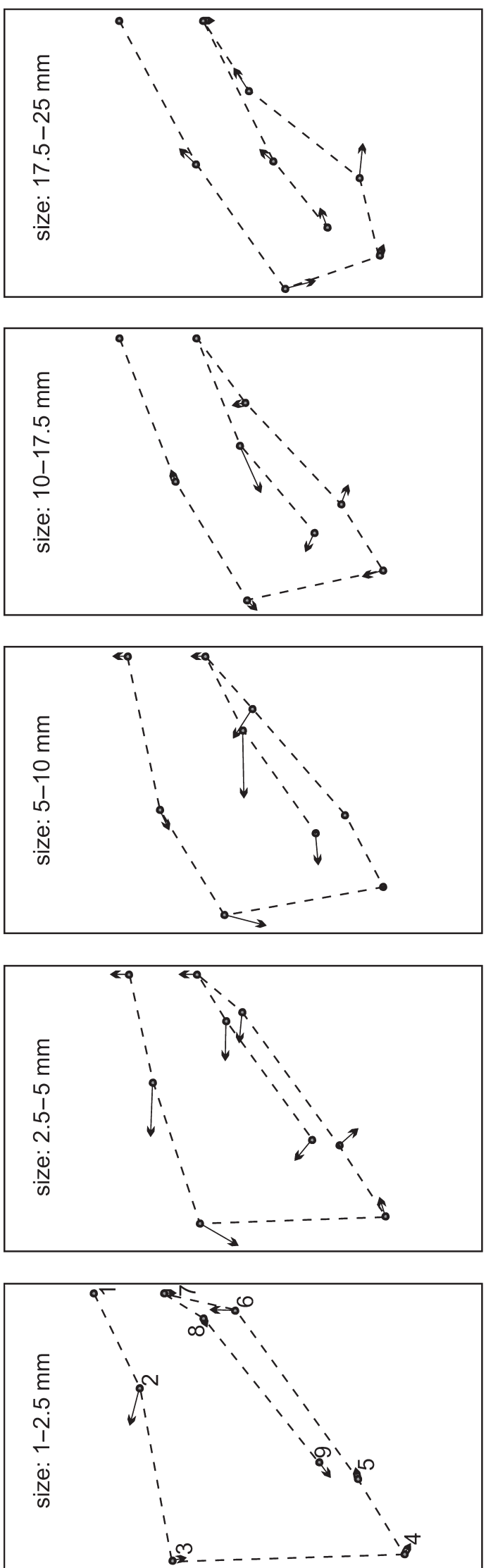
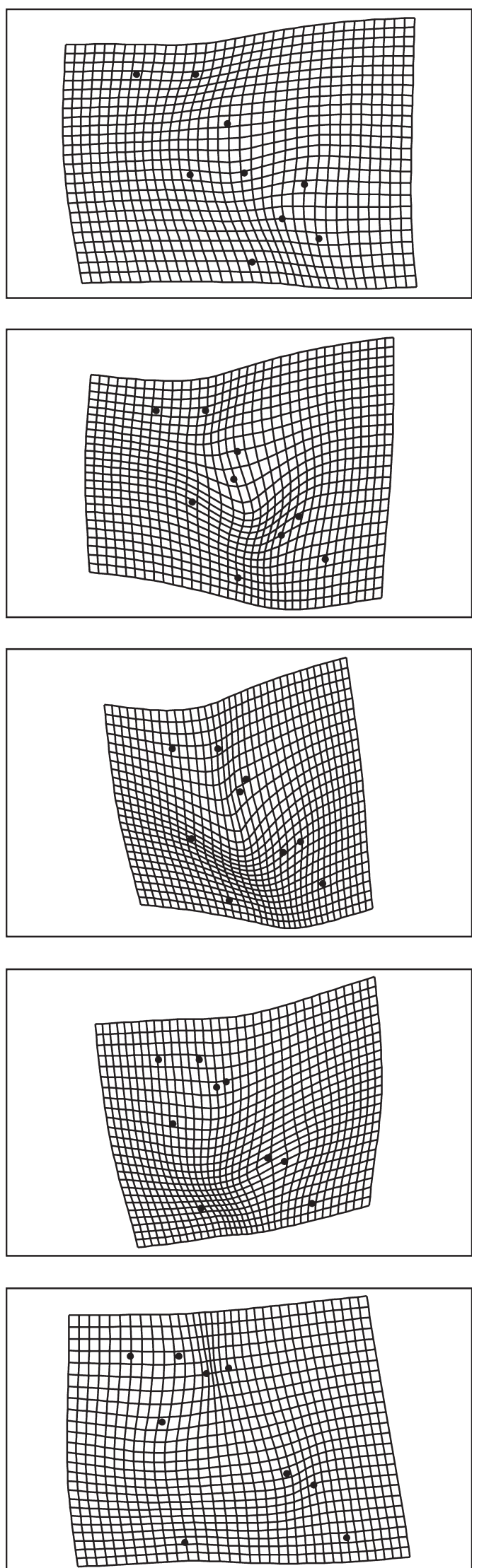

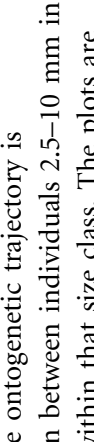

$\nsubseteq$ ह

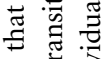

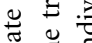

E

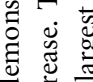

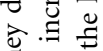

$\exists . \tilde{\mathrm{N}}$

造言

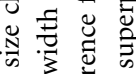

芯造离.

:

ส

$\stackrel{\square}{*} \Xi$

氜 चี

듬

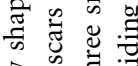

3 क

के

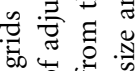

. 옳

胥 肎

웡

चี 들

苛. 结

ह

氜 氙

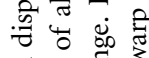

플 矛

苛泀芯

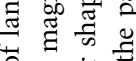

bo

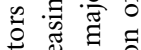

ठั

$>$ 용

보

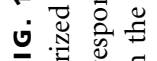

प

เ

婧芯 
1989), ontogenetic allometry of the pedicle muscle system in Terebratalia transversa contributes to the decrease in rotation ability.

The temporal correlation between the observed increase of distance between adjustor scars, of width of cardinal process, and of elevation of outer hinge plates above the valve floor at a length of $2.5-10 \mathrm{~mm}$ on one hand, and the observed decrease in rotation at a length of $2.5-5 \mathrm{~mm}$ on the other hand, support the hypothesis that the decrease in rotation angle observed in living Terebratalia transversa is related to ontogenetic changes in the dorsal attachment points of dorsal pedicle muscles. This agreement between ontogenetic changes in the observed reorientation ability and the ontogeny of internal morphological structures implies that the rotation angle is mechanically constrained in the adult stage because contraction of dorsal pedicle muscles is functionally handicapped. However, the misfit between the predicted rotation based on the angle $\alpha$ (i.e. adults should show rotations of about 20-25 degrees) and the observed rotation on living individuals (i.e. complete absence of rotation in adults) implies that some additional, morphological or ecological factors limit reorientation of the adult Terebratalia transversa.

In addition to the ontogenetic change in reorientation, several aspects of ecology substantially change over the ontogeny of most brachiopods. Brachiopods change their feeding flow configuration with size (Rudwick 1962, 1970), perceive their fluid environment at higher Reynolds numbers with size increase (Vogel 1981; Carlson 1983, 1986), and emerge from the substrate-related boundary layer with size increase (Carlson 1983). Terebratalia transversa juveniles possess trocholophe $(<1 \mathrm{~mm})$ and schizolophe lophophore types $(<2.5 \mathrm{~mm})$, in contrast to subadults and adults, which are characterized by zygolophe (2.5-5 mm) and plectolophe lophophore types (> $5 \mathrm{~mm}$ ) (Atkins 1959; Dhar et al. 1997). At a length of about $2.5 \mathrm{~mm}$, the configuration of the lophophore changes from a two-dimensional ring to a three-dimensional folded ring and the direction of inhalant and exhalant current flows, by active pumping, changes in Terebratalia transversa (Carlson 1983, 1987a, 1987b). The zygolophe-type configuration is characterized by an adulttype current flow regime with median excurrent flow and lateral incurrent flows (Rudwick 1962). At this stage, pressure distributions act in concert with active pumping under orientation with the anterior-posterior shell axis perpendicular to the current direction (LaBarbera 1977). Therefore, Terebratalia transversa achieves its preferred 'adult' orientation with respect to water currents only after development of the zygolophe lophophore.

Small juveniles likely experience a different fluid environment than adults owing to the dominance of viscous forces instead of inertial forces (Vogel 1981), and high flow resistance but low total flow rates (Grünbaum et al. 1998; Sherrard and LaBarbera 2005). Under a current speed of $1-2 \mathrm{~cm} / \mathrm{s}$, juveniles smaller than $3 \mathrm{~mm}$ in length are living within the substrate-associated boundary layer (Carlson 1983, 1986, 1987a, 1987b). Terebratalia transversa starts emerging into the free stream layer at these low current velocities, approximately at the time when they change their lophophore type to the adult configuration (Carlson 1983, 1986). Terebratalia transversa thus reorients to the preferred orientation with respect to water currents at this stage because (1) the preferred pre-zygolophe orientation differs from the orientation of adults, and (2) pre-zygolophe stages probably do not detect free stream velocity as do adults (Carlson 1983, 1986). Adult Terebratalia transversa living in subtidal habitats are oriented with the anterior-posterior shell axis perpendicular to the current direction (LaBarbera 1978), in accord with the preferred zygolophe and plectolophe orientation. We note that lack of reorientation was observed for adult Terebratalia transversa individuals that live in habitats differing in depth, substrate and current velocity (Thayer 1975, 1977; LaBarbera 1977; Schumann 1991). Although rotation can be inhibited by crowding or by growth within crevices in topographically-complex habitats, unrestricted individuals attached to flat substrates do not rotate in the adult stage.

It is thus remarkable that the rotation loss proceeds very rapidly after Terebratalia transversa can effectively attain its preferred zygolophe-plectolophe orientation with respect to water currents, and that this rotation loss is especially well captured by the complex allometric growth of dorsal pedicle muscle scars. This reorientation loss in Terebratalia transversa can represents an ontogenetic niche shift (Werner and Giliam 1984) because reorientation can confer feeding efficiency (LaBarbera 1977) and competition advantage of brachiopods (LaBarbera 1985). This shift can be associated with some substantial gains related to growth and survivorship of subadult and adult brachiopods that outweigh the disadvantages of substantially reduced reorientation ability at length of $5 \mathrm{~mm}$. The ontogenetic shift in rotation ability of Terebratalia transversa is species-specific; many other brachiopod species such as Terebratulina unguicula or Laqueus californianus actively reorient in the adult stage (LaBarbera 1977, 1978; Richardson 1981a).

\section{Morphological causes of reorientation loss}

Allometric ontogenetic increase in between-scar distance, increase in cardinal process width, and increase in elevation of scars above the valve floor closely correspond to the observed ontogenetic change in rotation angle in living individuals of Terebratalia transversa. The dorsal side 
of the angle $\alpha$ substantially changes its orientation from vertical to nearly horizontal during the ontogeny of Terebratalia transversa (i.e. outer hinge plates with attachment sites of dorsal pedicle muscles move in a ventral and lateral direction away from midline). The elevation of attachments points of the dorsal pedicle muscles above the valve floor and the allometric shift away from the valve midline thus decrease the angle $\alpha$. The ventral side of the angle $\alpha$ has a relatively constant orientation (approximately parallel with the commisural plane) in the ontogeny of Terebratalia transversa because the pedicle opening diameter shows isometric growth and ventral attachment points of the dorsal pedicle muscles do not change their position during ontogeny. Therefore, the change in angle $\alpha$ is mainly driven by the change in its dorsal side that is captured by morphological changes in dorsal pedicle muscle scars and cardinalia.

In the adult stage, the rotation ability is effectively prohibited not only by increased between-scar distance, but by a very wide cardinal process that shows complex allometric growth. The changes in size of scars of dorsal pedicle muscles measured by the adjustor scar width (i.e, scar size decrease is accelerated later in ontogeny) and pedicle opening width (i.e. isometric growth) seems to have a weak relationship to the observed decrease in reorientation ability of Terebratalia transversa. Marked changes in morphology of the loop of Terebratalia transversa (Atkins 1959) have little effect on the shape of cardinalia, and the between-crural distance shows isometric growth. Similarly, the width of cardinalia constrains inner socket ridges, but cardinalia width shows more or less isometric growth.

Other morphological factors that can reduce reorientation loss can be related to the presence of stout pedicle connectives - tissues that connect the pedicle with inner socket ridges in adult individuals of Terebratalia transversa (LaBarbera 1978). Pedicle connectives increase in extent with age and can oppose the contraction of dorsal pedicle muscles (LaBarbera 1978; Carlson 1986). The highly depressed shape of the pedicle bulb can also reduce the rotation potential of adults.

\section{Ecological consequences of reorientation loss}

On one hand, the ontogenetic reduction in reorientation ability can affect ecological performance of Terebratalia transversa by decreasing feeding efficiency (if current directions are variable). On the other hand, loss of reorientation ability can decrease vulnerability to dislodgment by currents and biotic disturbance (1) by minimizing torque around the pedicle axis and/or by (2) shifting energy investment into attachment strength at the expense of the cost involved in reorientation. For example, under space- and food-limitation and variable flow directions, activity of pedicle muscles enhances the ability of brachiopods to use ambient currents that augment lophophore-generated flow through the mantle cavity (LaBarbera 1977, 1981), and prevents crowding from other animals settled nearby and aids in competion for space (LaBarbera 1977, 1985). Under constant flow directions, it can be advantageous for Terebratalia transversa to orient to the preferred orientation in the juvenile stage, and then to reduce vulnerability to physical or biotic dislodgement by reducing torque around the pedicle and also to decrease energetic costs of reorientation. Under high levels of disturbance, the loss of dorsal adjustor torque around the pedicle can be necessary to permit tight adhesion of the shell to the substrate via strong ventral pedicle muscles; restricting dorsal muscle activity in the adult stage increases shell protection against dislodgement. The loss of reorientation ability can thus be a consequence of changes that strengthen substrate attachment. However, we also stress that changes in the shape of cardinalia and the position of dorsal-pedicle muscle attachment may be a consequence of selection pressure on other morphological traits, and the change in rotation ability may be related to such hitchhiking effects (e.g. Wagner 1996). For example, widening the cardinal process serves to increase the stability of the valves during opening and closing by spreading apart the diductor muscle origins. In addition, an ontogenetic increase in shell convexity owing to maximizing mantle-cavity volume will force elevation of hinge plates above the dorsal valve floor, and thus can also reduce the angle $\alpha$.

Everything else being equal, the feeding efficiency of immobile Terebratalia transversa would be diminished relative to brachiopods with active reorientation. However, under high food supply, the ability to reduce vulnerability to dislodgement may overwhelm negative effects caused by the loss of reorientation ability. Submarine habitats of San Juan Islands are characterized by seasonally-variable but mostly nutrient-rich and plankton-rich waters (Mackas and Harrison 1997; Strom et al. 2001; Zamon 2002). A strong, tidally-induced mixing of open ocean and estuarine waters ensures that waters are rich in nutrients throughout the year, and Terebratalia transversa commonly occurs in San Juan Islands habitats with moderate to high currents (LaBarbera 1977). Both high primary productivity and high current speeds can thus ensure that competition for food is not likely to play an important role in the distribution of Terebratalia transversa. This species also commonly occurs in crevices within topographically-complex substrates, formed either by boulder undersides and caves or by solitary ascidians and giant barnacles (Tomašových 2008a, b). Such crevices are inevitably affected by thicker benthic boundary layers, slower and less predictable water currents, and increased risk of 
feeding current recirculation, and thus can limit suspension-feeders. In addition, the direction of water flow to which juveniles reorient after they achieve the zygolophe lophophore can change during their growth because they are mostly surrounded by other organisms (e.g. Balanus nubilus, solitary ascidians, fleshy algae, cheilostomid encrusting and erect bryozoans). Therefore, it is interesting to note that population density of Terebratalia transversa increases from open and exposed substrates towards crevices and cryptic habitats (Tomašových 2008a, 2008b). This observation might indicate that competition for food is less limiting than other factors, such as disturbance, that can reduce brachiopod density on exposed substrates.

Although adult individuals Terebratalia transversa in this area are rarely affected by carnivorous predators (Mauzey et al. 1968; Thayer 1985), high consumer pressure on juveniles and small-sized Terebratalia transversa is probably mainly represented by the grazing activity of the highly abundant sea urchins Strongylocentrotus franciscanus and S. droebachiensis in subtidal habitats, and by the grazing activity of limpets and chitons in the intertidal zone (Tomašových 2008a). In such habitats with high biotic disturbance and high food supply, it is possible that the rapid loss of rotation ability in Terebratalia transversa is related to higher shell protection (reduction of torques around the pedicle axis) and/or to higher energy investment in attachment strength in the juvenile/subadult stages rather than in reorientation. For example, trade-off between foraging efficiency and predation risk predicts that animals should reduce activity levels under high consumer pressure or high resource availability (e.g. Dill 1987; Lima and Dill 1990; McNamara and Houston 1987; 1994; Abrams 1991; Anholt 1998; Anholt and Werner 1995; Werner and Anholt 1993).

Attachment strength of pedunculate brachiopods is comparable to that of byssally-attached mussels in the adult stage (Thayer 1975). However, in contrast to byssally-attached and byssally-cemented bivalves (Yonge 1977; Yamaguchi 1998), juvenile brachiopods cannot re-attach once they are detached from the substrate by physical or biotic disturbances. This inability to re-attach makes them more vulnerable to grazing pressure than epifaunal bivalves. Instead, Terebratalia transversa in San Juan Channel seems to utilize several mechanisms that can enhance their survivorship under intense consumer pressure such as a possible evolutionary adoption of chemical defenses (Thayer 1985), preferential occurrence in spatial refuges such as rock crevices (Thayer 1977), or preferential association with predation-free organisms such as ascidians (Young 1989). However, close adhesion to the substrate with a shell-protected pedicle and resistance to torque loads owing to the loss of rotation might substantially aid in the resistance of small juveniles and subadults of
Terebratalia transversa to dislodgement by grazers or other predators.

Terebratalia transversa attains smaller median length in crevices than on exposed substrates because the proportion of small-sized individuals is lower on exposed than on protected substrates. Although brachiopod larvae primarily prefer rugose substrates for settlement, such preference should not lead to rarity of small-sized individuals relative to large individuals on exposed substrates. We note that these differences in body size refer to brachiopod populations sampled among boulders along three 50$100 \mathrm{~m}$-long transects on the eastern side of San Juan Channel. Thus, we believe it is likely that brachiopods in crevices and on exposed substrates are derived from the same larval pool; spatial or temporal variations in fecundity should not affect these differences. Observed size differences are more likely related to differences in mortality and growth rates. Individuals on exposed substrates (i.e., those more likely affected by strong grazing effects and/or higher current speeds owing to thinner benthic boundary layer) are (1) either characterized by lower juvenile survivorship than individuals in crevices, and/or (2) their growth rate is lower in crevices. We suggest that lower juvenile mortality contributes to the higher proportion of small individuals in crevices because the population density of Terebratalia transversa also decreases from crevices towards exposed flat surfaces (Tomašových 2008a, 2008b).

\section{CONCLUSIONS}

The northeastern Pacific brachiopod Terebratalia transversa undergoes major changes in ecology and morphology during ontogeny. In addition to the ontogenetic changes also seen in other pedunculate brachiopods, such as changes in lophophore configuration and changes in fluid viscosity they experience with increasing size, Terebratalia transversa shows a unique ontogenetic decrease in active rotation angle that correlates with complex allometric shifts in position and size of the dorsal pedicle scars and diductor scars. The temporal correlation between the observed increase of distance between adjustor scars, of the width of the cardinal process, and of the elevation of outer hinge plates above the valve floor on one hand, and the observed decrease in rotation on the other hand, support the hypothesis that the decrease in rotation angle observed in living Terebratalia transversa is mainly related to ontogenetic changes in the dorsal attachment points of dorsal pedicle muscles. The ontogenetic shift in rotation ability is partly a consequence of the rapid ontogenetic decrease in rotation angle owing to restriction of muscle contraction, although other morphological features can limit rotation in the adult stage. 
We hypothesize that reorientation loss can be a consequence of morphological changes that strengthen substrate attachment. This reorientation loss allows individuals to increase their ability to protect themselves by maximizing resistance to torque and/or by shifting energy investments into attachment strength at the expense of the cost involved in reorientation. The ontogenetic niche shift towards the loss of reorientation ability is probably governed by the disturbance pressure on Terebratalia transversa because this brachiopod attains smaller median length in crevices than on exposed substrates small-sized individuals are rare on flat exposed substrates, indicating higher juvenile mortality on flat substrates that are less protected from dislodgement disturbances. Terebratalia transversa is abundant in habitats with high productivity, strong and predictable water currents and relatively high grazing pressure, where low activity levels can be predicted by a trade-off between resource acquisition and predation risk. In contrast, the maintenance of reorientation ability in the adult stage can be more beneficial for brachiopods living in habitats with variable or food-poor water currents and/or high competition pressure.

Acknowledgements. We thank the University of Washington and Friday Harbor Laboratories for support of this research, and Fernando Alvarez, Michał Kowalewski, and Melanie Hopkins for critical comments. Adam Tomašových also thanks Slovak Research and Development Agency (APVV-0248-07), the Slovakian Scientific Grant Agency (2/0068/08), the National Science Foundation (EAR-0345897), and acknowledges the support from the University of Southern California Sea Grant Program, National Oceanic and Atmospheric Administration, U.S. Department of Commerce, under grant number NA07OAR4170008.

\section{REFERENCES}

ABERHAN, M. 1994. Guild-structure and evolution of Mesozoic benthic shelf communities. Palaios, 9, 516-545.

- KIESSLING, W. and FÜRSICH, F. T. 2006. Testing the role of biological interactions in the evolution of mid-Mesozoic marine benthic ecosystems. Paleobiology, 32, 259-277.

ABRAMS, P. A. 1991. The relationship between food availability and foraging effort: effects of life history and time scale. Ecology, 72, 1242-1252.

ALDRIDGE, A. E. 1998. Brachiopod outline and the importance of the logarithmic spiral. Paleobiology, 24, 215-226.

1999. Brachiopod outline and episodic growth. Paleobiology, 25, 471-482.

ALLMON, W. D. 1994. Patterns and processes of heterochrony in Lower Tertiary turritelline gastropods, U.S. Gulf and Atlantic Coastal Plains. Journal of Paleontology, 68, 80-95.

ÁLVAREZ, F. 1990. Devonian athyrid brachiopods from the Cantabrian Zone (NW Spain). Biostratigraphie du Paleozoique, $11,1-311$.
—_EMIG, C. C., ROLDÁN, C. and ViéiteZ, J. M. 2005. Lophophorata: Phoronida, Brachiopoda. Fauna Ibérica, 27, $1-273$.

ANHOLT, B. R. and WERNER, E. E. 1995. Interaction between food availability and predation mortality mediated by adaptive behavior. Ecology, 76, 2230-2234.

- 1998. Preditable changes in predation mortality as a consequence of changes in food availability and predation risk. Evolutionary Ecology, 12, 729-738.

ATKINS, D. 1959. The growth stages of the lophophore and loop of the brachiopod Terebratalia transversa. Journal of Morphology, 105, 401-426.

AUCLAIR, A.-C., JOACHIMSKI, M. M. and LÉCUYER, C. 2003. Deciphering kinetic, metabolic and environmental controls on stable isotope fractionations between seawater and the shell of Terebratalia transversa (Brachiopoda). Chemical Geology, 202, 59-78.

AYAlA, F. J., VAlentine, J. W., DELACA, T. E. and ZUMWALT, G. S. 1975. Genetic variability of Antarctic brachiopod Liothyrella notorcadensis and its bearing on mass extinction hypotheses. Journal of Paleontology, 49, 1-9.

BAMBACH, R. K. 1993. Seafood through time: changes in biomass, energetics, and productivity in the marine ecosystems. Paleobiology, 19, 372-397.

BASSETT, M. G. 1984. Life strategies of Silurian brachiopods. Special papers in paleontology, 32, 237-263.

BOOKSTEIN, F. L. 1991. Morphometric tools for landmark data. Cambridge University Press, Cambridge, 435 pp.

BOURGET, E., DEGUISE, J. and DAIGLE, G. 1994. Scales of substratum heterogeneity, structural complexity, and the early establishment of a marine epibenthic community. Journal of Experimental Marine Biology and Ecology, 181, $31-51$.

BROMLEY, R. G. and SURLYK, F. 1973. Borings produced by brachiopod pedicles, fossil and Recent. Lethaia, 6, 349-365.

BRUNTON, C. H. C. 1996. The functional morphology of the Recent brachiopod Bouchardia rosea. Acta Zoologica, 77, 23-240.

—ÁLVAREZ, F. and MacKINNON, D. I. 1996. Morphological terms used to describe the cardinalia of articulate brachiopods: Homologies and recommendations. Historical Biology, 11, 9-41.

BUENING, N. and CARLSON, S. J. 1992. Geochemical investigation of growth in selected Recent articulate brachiopods. Lethaia, 25, 331-345.

BUSH, A. M., BAMBACH, R. K. and DALEY, G. M. 2007. Changes in theoretical ecospace utilization in marine fossil assemblages between the mid-Paleozoic and late Cenozoic. Paleobiology, 33, 76-97.

CARLSON, S. J. 1983. Behavior of juvenile brachiopods: orientation and flow patterns. Friday Harbor Laboratories Class Papers, 1-39.

- 1986. Ontogenetic and evolutionary trends in the articulate brachiopod hinge mechanism. Unpublished PhD thesis, University of Michigan, Ann Arbor, 268 pp.

— 1987a. Ontogenetic variation in articulate brachiopod hinge mechanics: an example of Terebratalia transversa. Geological Society of America, Abstracts with Programs, 19, 365. 
- 1987b. Behavior of juvenile articulate brachiopods: orientation and flow patterns through the mantle cavity. Geological Society of America, Abstracts with Programs, 19, 611.

- 1989. The articulate brachiopod hinge mechanism: morphological and functional variation. Paleobiology, 15, 364-386.

- 1992. Evolutionary trends in the articulate brachiopod hinge mechanism. Paleobiology, 18, 344-366.

CHAPMAN, B. E. and RICHARDSON, J. R. 1981. Recent species of Neothyris (Brachiopoda: Terebratellinae). New Zealand Journal of Zoology, 8, 157-161.

COHEN, B. L., BALFE, P., COHEN, M. and CURRY, G. B. 1991. Molecular evolution and morphological speciation in North-Atlantic brachiopods (Terebratulina spp.). Canadian Journal of Zoology, 69, 2903-2911.

— 1993. Molecular and morphometric variation in European populations of the articulate brachiopod Terebratulina retusa. Marine Biology, 115, 105-111.

CURRY, G. B. 1981. Variable pedicle morphology in a population of the Recent brachiopod Terebratulina septentrionalis. Lethaia, 14, 9-20.

— 1983. Ecology of the Recent deep-water rhynchonellid brachiopod Cryptopora from the Rockall Trough. Palaeogeography, Palaeoclimatology, Palaeoecology, 44, 93-102.

DATTilO, B. F. 2004. A New Angle on Strophomenid Paleoecology: Trace-Fossil Evidence of an Escape Response for the Plectambonitoid Brachiopod Sowerbyella rugosa from a Tempestite in the Upper Ordovician Kope Formation (Edenian) of Northern Kentucky. Palaios, 19, 332-348.

DHAR, S. R., LOGAN, A., MAcDONALD, B. A. and WARD, J. E. 1997. Endoscopic investigation of feeding structures and mechanisms in two plectolophous brachiopods. Invertebrate Biology, 116, 142-150.

DILL, L. M. 1987. Animal decision making and its ecological consequences: the future of aquatic ecology and behaviour. Canadian Journal of Zoology, 65, 803-811.

EMIG, C. C. 1989. Distributional patterns along the Mediterranean continental margin (upper bathyal) using Gryphus vitreus (Brachiopoda) densities. Palaeogeography, Palaeoclimatology, Palaeoecology, 71, 253-256.

FOOTE, M. 1993. Contributions of individual taxa to overall morphological disparity. Paleobiology, 19, 403-419.

FÜRSICH, F. T. and HURST, J. M. 1974. Environmental factors determining the distribution of brachiopods. Palaeontology, 17, 879-900.

GOULD, S. J. and LEWONTIN, R. C. 1979. The spandrels of San Marco and the Panglossian paradigm: a critique of the adaptationist programme. Proceedings of the Royal Society of London, B205, 581-598.

GRÜNBAUM, D., EYRE, D. and FOGELSON, A. 1998. Functional geometry of ciliated tentacular arrays in active suspension-feeders. Journal of Experimental Biology, 201, 25752589.

GURALNICK, R. and KURPIUS, J. 2001. Spatial and temporal growth patterns in the phenotypically variable Littorina saxatilis: surprising patterns emerge from chaos. 195227. In ZELDITCH, M. L. (ed.). Beyond heterochrony: the evolution of development. John Wiley \& Sons, New York, $371 \mathrm{pp}$.
JOLICOEUR, P. 1963. The multivariate generalization of the allometry equation. Biometrics, 19, 497-499.

KIM, K., SHEETS, H. D., HANEY, R. A. and MITCHELL, C. E. 2002. Morphometric analysis of ontogeny and allometry of the Middle Ordovician trilobite Triarthrus becki. Paleobiology, 28, 364-377.

KOEHL, M. A. R. 1996. When does morphology matter? Annual Reviews of Ecology and Systematics, 27, 501-542.

KOWALEWSKI, M., DYRESON, E., MARCOT, J. D., VARGAS, J. A., FLESSA, K. W. and HALLMAN, D. P. 1997. Phenetic discrimination of biometric singletons: paleobiological implications of morphospecies in the lingulide brachiopod Glottidia. Paleobiology, 23, 444-469.

- HOFFMEISTER, A. P., BAUMiller, T. K. and BAMBACH, R. K. 2005. Secondary evolutionary escalation between brachiopods and enemies of other prey. Science, 308, 1774-1777.

KRAUSE, R. A. 2004. An assessment of morphological fidelity in the sub-fossil record of a terebratulide brachiopods. Palaios, 19, 460-476.

LABARBERA, M. 1977. Brachiopod orientation to water movement. 1. Theory, laboratory behavior, and field orientations. Paleobiology, 3, 270-287.

- 1978. Brachiopod orientation to water movement: functional morphology. Lethaia, 11, 67-79.

1981. Water flow patterns in and around three species of articulate brachiopods. Journal of experimental marine biology and ecology, 55, 185-206.

1985. Mechanisms of spatial competition of Discinisca strigata (Inarticulata: Brachiopoda) in the intertidal of Panama. Biological Bulletin, 168, 91-105.

— 1989. Analyzing body size as a factor in ecology and evolution. Annual Reviews in Ecology and Systematics, 20, 97-117.

LEE, D. E., MackinNon, D. I., SMIRNOVA, T. N., BAKER, P. G., YU-GAN, J. and DONGLI, S. 2006. Terebratulida. 1965-2255. In KAESLER, R. L. (ed). Treatise on invertebrate paleontology, Part $\mathrm{H}$, Brachiopoda. 5 (revised). Geological Society of America, Boulder, Colorado, and University of Kansas Press, Lawrence, Kansas, 631 pp.

LEIGHTON, L. R. 2000. Environmental distribution of spinose brachiopods from the Devonian of New York: test of the soft substrate hypothesis. Palaios, 15, 184-193.

LESCINSKY, H. L. 1995. The life orientation of concavo-convex brachiopods: overturning the paradigm. Paleobiology, 21, 520-551.

LIMA, S. L. and DILL, L. M. 1990. Behavioral decision made under the risk of predation: a review and prospectus. Canadian Journal of Zoology, 68, 619-640.

LOGAN, A. 2007. Geographic distribution of extant articulated brachiopods. 3082-3115. In SELDEN, P. A. (ed). Treatise on invertebrate paleontology, Part $\mathrm{H}$, Brachiopoda. 6 (revised). Geological Society of America, Boulder, Colorado, and University of Kansas Press, Lawrence, Kansas, 906 pp.

BIANCHI, C. N., MORRI, C. and ZIBROWIUS, H. 2004. The present-day Mediterranean brachiopod fauna: diversity, life habits, biogeography and paleobiogeography. Scientia Marina, 68 (Supplement 1), 163-170. 
LÜTER, C. and COHEN, B. 2002. DNA sequence evidence for speciation, paraphyly and a Mesozoic dispersal of cancellothyridid articulate brachiopods. Marine Biology, 141, 65-74.

MACKAS, D. L. and HARRISON, P. J. 1997. Nitrogenous nutrient sources and sinks in the Juan de Fuca Strait/Strait of Georgia/Puget Sound estuarine system: assessing the potential for eutrophication. Estuarine, Coastal and Shelf Science, 44, $1-21$.

MAcKAY, S. and HEWITT, R. A. 1978. Ultrastructural studies on the brachiopod pedicle. Lethaia, 11, 331-339.

— MacKINNON, D. I. and WILliAMS, A. 1993. Ultrastructure of the loop of terebratulide brachiopods. Lethaia, 26, 367-378.

MacKINNON, D. I. 1977. The formation of muscle scars in articulate brachiopods. Philosophical Transactions of the Royal Society of London, B280, 1-27.

— SAITO, M. and ENDO, K. 1997. Morphology and systematics of the Recent Japanese brachiopod Shimodaia pterygiota gen. et sp. nov. (Laqueidae: Terebratulida). Paleontological Research, 1, 225-233.

MADIN, J. S., ALROY, J., ABERHAN, M., FÜRSICH, F. T., KIESSLING, W., KOSNIK, M.A. and WAGNER, P. J. 2006. Statistical independence of escalatory ecological trends in Phanerozoic marine invertebrates. Science, 312, 897-900.

MANCEÑIDO, M. O. and WALLEY, C. D. 1979. Functional morphology and ontogenetic variation in the Callovian brachiopod Septirhynchia from Tunisia. Palaeontology, 22, 317337.

MAUZEY, K. P., BIRKELAND, C. and DAYTON, P. K. 1968. Feeding behavior of asteroids and escape responses of their prey in the Puget Sound region. Ecology, 49, 603-619.

MCGHEE, G. R. . JR 1980. Shell form in the biconvex articulate Brachiopoda - a geometric analysis. Paleobiology, 6, 5776.

MCKINNEY, M. L. 1984. Allometry and heterochrony in an Eocene echinoid lineage: morphological change as a by-product of size selection. Paleobiology, 10, 407-419.

MCNAMARA, J. M. and HOUSTON, A. I. 1987. Starvation and predation as factors limiting population size. Ecology, 68, $1515-1519$.

_ 1994. The effect of a change in foraging options on intake rate and predation rate. American Naturalist, 144, 9781000.

NOVACK-GOTTSHALL，P. M. 2007. Using a theoretical ecospace to quantify the ecological diversity of Paleozoic and modern marine biotas. Paleobiology, 33, 273-294.

OSTROW, D. R., WING, S. R., MLADENOV, P. V. and ROY, M. S. 2001. Genetic differentiation of Terebratella sanguinea in the New Zealand fiords: a dispersal barrier in the marine environment? 150-158. In BRUNTON, C. H. C., COCKS, R. and LONG, S. (eds). Brachiopods past and present. Taylor and Francis, London, $441 \mathrm{pp}$.

PAINE, R. T. 1969. Growth and size distribution of the brachiopod Terebratalia transversa Sowerby. Pacific Science, 23, 337-343.

PECK, L. S. 1996. Metabolism and feeding in the Antarctic brachiopod Liothyrella uva: a low energy lifestyle species with restricted metabolic scope. Proceedings of the Royal Society of London, 263, 223-228.

PLOTNICK, R. E. 1985. Lift-based mechanisms for swimming in eurypterids and portunid crabs. Transactions of the Royal Society of Edinburgh, 76, 325-337.

— and BAUMILLER, T. K. 2000. Invention by evolution: functional analysis in paleobiology. 305-323. In ERWIN, D. H. and WING, S. L. (eds.). Deep time. Supplement to Paleobiology, 26. University of Chicago Press, Chicago, 371 pp.

R DEVELOPMENT CORE TEAM (2007) R: A language and environment for statistical computing. R Foundation for Statistical Computing, Vienna, Austria. http://www.R-project.org.

RHODES, M. C. and THOMPSON, R. J. 1993. Comparative physiology of suspension-feeding in living brachiopods and bivalves: evolutionary implications. Paleobiology, 19, 322-334.

RICHARDSON, J. R. 1975. Growth patterns of the loop and cardinalia in five Recent terebratellid species. Proceedings of the Royal Society of Victoria, 87, 197-205.

_ 1981a. Brachiopod and pedicles. Paleobiology, 7, 87-95.

— 1981b. Distribution and orientation of six articulate brachiopod species from New Zealand. New Zealand Journal of Zoology, 8, 189-196.

1987. Brachiopods from carbonate sands of the Australia shelf. Proceedings of the Royal Society of Victoria, 99, 37-50.

-1994. Origins and dispersal of a brachiopod family - the systematics, biogeography and evolution of the family Terebratellidae. Proceedings of the Royal Society of Victoria, 106, $17-29$.

- 1997. Ecology of articulated brachiopods. 441-462. In KAESLER, R. L. (ed.). Treatise on invertebrate paleontology, Part H, Brachiopoda. 1 (revised). Geological Society of America, Boulder, Colorado, and University of Kansas Press, Lawrence, Kansas, 539 pp.

— and WATSON, J. E. 1975. Form and function in a Recent free living brachiopod Magadina cumingi. Paleobiology, 1, 379-387.

_ and MINEUR, R. J. 1981. Differentiation of species of Terebratella (Brachiopoda: Terebratellinae). New Zealand Journal of Zoology, 8, 163-167.

RICKLEFS, R. E. and MILES, D. B. 1994. Ecological and evolutionary inferences from morphology: an ecological perspective. 13-41. In WAINWRIGHT, P. C. and REILLY, S. M. (eds). Ecological Morphology: integrative organismal biology. The University of Chicago Press, Chicago-London, $384 \mathrm{pp}$.

ROOPNARINE, P. D. 2001. Testing the hypothesis of heterochrony in morphometric data: lessons from a bivalved mollusk. 271-303. In ZELDITCH, M. L. (ed.). Beyond heterochrony: the evolution of development, John Wiley \& Sons, New York, 371 pp.

RUDWICK, M. J. S. 1962. Filter feeding mechanisms in some brachiopods from New Zealand. Journal of Linnean Society (Zoology), 44, 592-615.

1970. Living and fossil brachiopods. Hutchinson University Library, London, 199 pp.

SCHUMANN, D. 1991. Hydrodynamic influences in brachiopod shell morphology of Terebratalia transversa (Sowerby) from the San Juan Islands, USA. 265-272. In M A cKINNON, 
D. I., LEE, D. E. and CAMPBELL, J. D. (eds). Brachiopods Through Time. Proceedings of the 2nd International Brachiopod Congress. Balkema, Rotterdam, 447 pp.

SEGER, J. and STUBBLEFIELD, J. W. 1996. Optimization and adaptation. 93-123. In ROSE, M. R. and LAUDER, G. V. (eds.). Adaptation. Academic Press, San Diego, 511 pp.

SEPKOSKI, J. J. JR and MILLER, A. 1985. Evolutionary faunas and the distribution of Paleozoic benthic communities in space and time. 153-190. In VALENTINE, J. W. (ed.). Phanerozoic diversity patterns: profiles in macroevolution. Princeton University Press, Princeton, $441 \mathrm{pp}$.

SHERRARD, K. M. and LABARBERA, M. 2005. Form and function in juvenile ascidians. I. Implications of early juvenile morphologies for performance. Marine Ecology Progress Series, 287, 127-138.

SIMÕES, M. G., RODRIGUES, S. C. and KOWALEWSKI, M. 2007. Comparative analysis of drilling frequencies in Recent brachiopod-mollusk associations from the southern Brazilian shelf. Palaios, 22, 143-154.

STANLEY, S. M. 1970. Relation of shell form to life habits in the Bivalvia (Mollusca). Geological Society of America, Memoir, 125, 1-296.

STRICKER, S. A. and REED, C. G. 1985. Development of the pedicle in the articulate brachiopod Terebratalia transversa (Brachiopoda, Terebratulida). Zoomorphology, 105, 253-264.

STROM, S. L., BRAINARD, M. A., HOLMES, J. L. and OLSON, M. B. 2001. Phytoplankton blooms are strongly influenced by microzooplankton grazing in coastal North Pacific waters. Marine Biology, 138, 355-368.

SURLYK, F. 1972. Morphological adaptations and population structure of the Danish Chalk brachiopods (Maastrichtian, Upper Cretaceous). Kongelige Danske Videnskabernes Selskab, Biologiske Skrifter, 19, 2-57.

THAYER, C. W. 1975. Strength of pedicle attachment in articulate brachiopods: ecologic and paleoecologic significance. Paleobiology, 1, 388-399.

— 1977. Recruitment, growth, and mortality of a living articulate brachiopod, with implications for the interpretation of survivorship curves. Paleobiology, 3, 98-109.

— 1983. Sediment-mediated biological disturbance and the evolution of marine benthos. 479-625. In TEVESZ, M. J. S. and MCCALL, P. L. (eds). Biotic interactions in recent and fossil benthic communities. Plenum Press, New York, 837 pp.

1985. Brachiopods versus mussels: competition, predation, and palatability. Science, 228, 1527-1528.

TOMAŠOVÝCH, A. 2008a. Substrate exploitation and resistance to biotic disturbance in the brachiopod Terebratalia transversa and the bivalve Pododesmus macrochisma. Marine Ecology Progress Series, 363, 157-170.

- 2008b. Evaluating neutrality and escalation hypothesis in brachiopod communities from shallow, high-productivity habitats. Evolutionary Ecology Research, 10, 667-698.

VALENTINE, J. W. and JABLONSKI, D. 1983. Larval adaptations and patterns of brachiopod diversity in space and time. Evolution, 37, 1052-1061.

VERMEIJ, G. J. 1977. The Mesozoic marine revolution: evidence from snails, predators and grazers. Paleobiology, 37, 245-258.
VOGEL, S. 1981. Life in moving fluids: the physical biology of flow. W. Grant Press, Boston, Massachusetts, 352 pp.

WAGNER, P. 1996. Contrasting the underlying patterns of active trends in morphological evolution. Evolution, 50, 990-1007.

WAINWRIGHT, P. C. 1994. Functional morphology as a tool in ecological research. 42-59. In WAINWRIGHT, P. C. and REILLY, S. M. (eds). Ecological Morphology: integrative organismal biology. The University of Chicago Press, ChicagoLondon, $384 \mathrm{pp}$.

WALTERS, L. J. and WETHEY, D. S. 1996. Settlement and early post-settlement survival of sessile marine invertebrates on topographically complex surfaces: the importance of refuge dimensions and adult morphology. Marine Ecology Progress Series, 137, 161-171.

WEBSTER, M., SHEETS, H. D. and HUGHES, N. C. 2001. Allometric patterning in trilobite ontogeny: testing for heterochrony in Nephrolenellus. 105-144. In ZELDITCH, M. L. (ed.). Beyond heterochrony: the evolution of development. John Wiley \& Sons, New York, $371 \mathrm{pp}$.

2007. Ontogeny and evolution of the early Cambrian trilobite genus Nephrolenellus (Olenelloidea). Journal of Paleontology, 81, 1168-1193.

WERNER, E. E. and GILIAM, J. F. 1984. The ontogenetic niche and species interactions in size-structured populations. Annual Reviews of Ecology and Systematics, 15, 393-425.

- and ANHOLT, B. R. 1993. Ecological consequences of the trade-off between growth and mortality rates mediated by foraging activity. American Naturalist, 142, 242-272.

WILliAMS, A. and HEWITT, R. A. 1977. The delthyrial covers of some living brachiopods. Proceedings of the Royal Society of London, 197, 105-129.

—_ and HURST, J. M. 1977. Brachiopod evolution. 79-121. In HALLAM, A. (ed.). Patterns of Evolution as Illustrated by the Fossil Record, Elsevier, Amsterdam, 591 pp.

YAMAGUCHI, K. 1998. Cementation vs mobility: development of a cemented byssus and flexible mobility in Anomia chinensis. Marine Biology, 132, 651-661.

YONGE, C. M. 1977. Form and Evolution in the Anomiacea (Mollusca: Bivalvia)-Pododesmus, Anomia, Patro, Enigmonia (Anomiidae): Placunanomia, Placuna (Placunidae Fam. Nov.). Philosophical Transactions of the Royal Society of London, Series B, Biological Sciences, 276, 453-523.

YOUNG, C. M. 1989. Selection of predator-free settlement sites by larval ascidians. Ophelia, 30, 131-140.

ZAMON, J. E. 2002. Tidal changes in copepod abundance and maintenance of a summer Coscinodiscus bloom in the southern San Juan Channel, San Juan Islands, USA. Marine Ecology Progress Series, 226, 193-210.

ZELDITCH, M. L., BOOKSTEIN, F. L. and LUNDRIGAN, B. L. 1993. Ontogeny of integrated skull growth in the cotton rat Sigmodon fulviventer. Evolution, 46, 1164-1180.

-SWIDERSKI, D. L., SHEETS, H. D. and FINK, W. L. 2004. Geometric morphometrics for biologists: a Primer. Elsevier Academic Press, San Diego, 443 pp.

ZEZINA, O. N. 2001. Global surface-water circulation and the main features of brachiopod biogeography. 102-107. In BRUNTON, C. H. C., COCKS, R. and LONG, S. (eds). Brachiopods past and present. Taylor and Francis, London, 441 pp. 